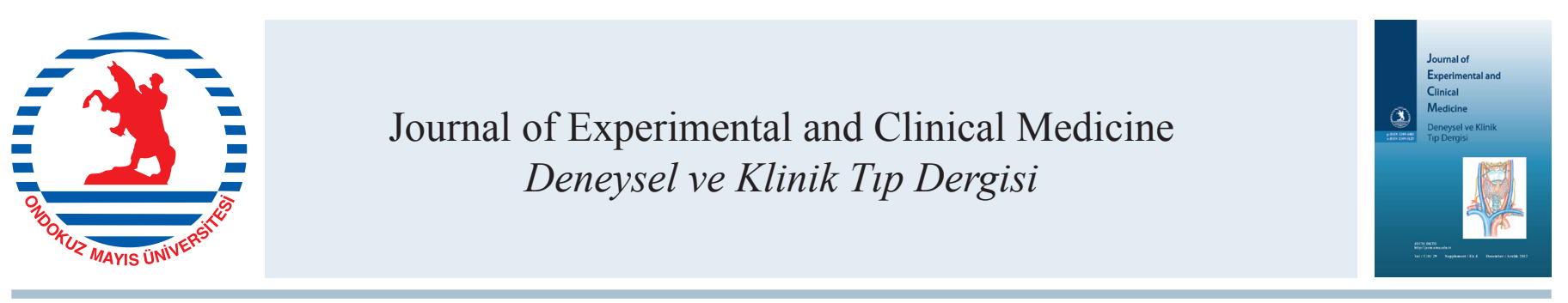

Derleme / Review

doi: $10.5835 /$ jecm.omu.29.s4.016

\title{
Tiroit sintigrafisi
}

\section{Thyroid scintigraphy}

\author{
Fevziye Canbaz Tosun
}

Ondokuz Mayıs Üniversitesi, Tıp Fakültesi, Nükleer Tıp Anabilim Dalı, Samsun, Türkiye

\begin{tabular}{|c|c|}
\hline MAKALE I & GÍLERİ \\
\hline Makale geç & \\
\hline Geliş tarihi & $: 31 / 05 / 2012$ \\
\hline Kabul tarihi & : $03 / 12$ / 2012 \\
\hline
\end{tabular}

\section{* Yazışma Adresi:}

Fevziye Canbaz Tosun

Ondokuz Mayıs Üniversitesi,

Tıp Fakültesi,

Nükleer Tıp Anabilim Dalı,

Kurupelit 55139, Samsun

e-posta: fcanbaz@omu.edu.tr

\section{Anahtar Kelimeler:}

Tiroit sintigrafisi

Hipertiroidi

Tiroit kanseri

SPECT/BT

PET/BT

\section{Keywords:}

Thyroid scintigraphy

Hyperthyroidism

Thyroid cancer

SPECT/CT

$\mathrm{PET} / \mathrm{CT}$

\section{ÖZET}

Tiroit hastalıklarında radyonüklit uygulamalar, ilk olarak İkinci Dünya Savaşı’ndan sonra ${ }^{131}$ 'Iyot' un tedavide kullanımı ile başlamıştır. Gama sintilasyon dedektörlerinin 1950'lerin erken döneminde kullanıma girmesiyle tiroit görüntüleme çalışmaları da tanısal yöntemler arasında yerini almıştır. Nükleer Tıpta, 1980'lerden beri kullanılan Single Photon Emission Tomography (SPECT) ve 1990'larda klinik kullanıma giren Positron Emission Tomography (PET) inceleme teknikleri daha öncesinde alış1lagelmiş 2 boyutlu planar görüntülemeye ek olarak radyotrasör dağılımı ve lokalizasyonunun 3 boyutlu olarak değerlendirilmesine olanak verir. SPECT ve PET kameralarına Bilgisayarlı Tomografi (BT)'nin eklenmesiyle oluşturan hibrit cihazlar, ek olarak atenüasyon düzeltmesi ve lezyonun doğru olarak yerini belirlemeyi sağlarlar. SPECT/BT ve PET/BT günümüz rutininde benign ve malign tiroit hastalıklarının değerlendirilmesinde yaygın olarak uygulanmaktadır. Tiroit sintigrafisi uzun yıllardır çeşitli tiroit hastalıklarının tanısında kullanılmaktadır. Günümüzde tiroit ultrasonografisinin artan kullanımı ve tiroit nodüllerinde tanısal perkütan aspirasyon biyopsisinin yoğun uygulanması ile tiroit sintigrafisi eskiye oranla daha az tercih edilir olmuştur. Tiroit sintigrafisi bezin fizyoloji ve fonksiyonunu göstermesi nedeniyle, hipertiroidi başta olmak üzere hasta yönetiminde hali hazırda önemli role sahiptir.

J. Exp. Clin. Med., 2012; 29:S289-S300

\begin{abstract}
Radionuclide methods in thyroidal diseases were firstly initiated after the Second World War by the use of ${ }^{131}$ Iodine in therapy. By the early 1950's, radionuclide thyroid imaging studies have superseded among the diagnostic modalities when gamma scintillation detectors came into the clinical usage. In Nuclear Medicine, since 1980's, Single Photon Emission Tomography (SPECT) and Positron Emission Tomography (PET) imaging which came into clinical usage in 1990's, provide three dimensional evaluation of radiotracer distribution in addition to conventional two dimensional planar scan. Hybrid systems which were composed of SPECT and CT or PET and CT scan, produce images with improved attenuation correction and anatomic localization. SPECT/CT and PET/ CT scans are widely performed in benign and malign thyroid diseases in current rutin practice. For many years, thyroid scan has been used in the diagnostic evaluation of several thyroid diseases. The utility of thyroid scintigraphy to characterize thyroid nodules has significantly decreased over the past decade because of the increasing use of thyroid ultrasonography and fine needle aspiration biopsy. Nonetheless, the ability of nuclear medicine to assess physiology and function makes it an indispensable tool in the management of patients with thyroid disease, especially in hyperthyroidism.

J. Exp. Clin. Med., 2012; 29: S289-S300
\end{abstract}

\section{Giriş}

Tiroit hastalıklarında radyonüklit uygulamalar, ilk olarak İkinci Dünya Savaşı'ndan sonra ${ }^{131}$ İyot'un tedavide kullanımı ile başlamıştır. Gama sintilasyon dedektörlerinin 1950'lerin erken döneminde kullanıma girmesiyle tiroit görüntüleme çalışmaları tanısal yöntemler arasında yerini almıştır. Tiroit hastalıklarının tanı ve tedavisinde radyoaktif iyot içeren radyonüklit metotlar, tümüyle fizyolojik temellere dayanır ve gerek nükleer tıp ve gerekse nükleer tıp dışı incelemeler arasında tiroide spesifik olmaları nedeniyle özel önem ve ayrıcalık taşırlar. 


\section{Genel endikasyonlar \\ Tiroit sintigrafisi}

Tiroit dokusunun varlığg, büyüklüğü, şekli, yeri ve fonksiyonunun değerlendirilmesi için kullanılan bir görüntüleme metodudur. Genel olarak aşağıdaki klinik endikasyonlarda uygulanır (Becker ve ark., 1999; Töre ve ark., 2003):

-Nodüler veya diffüz guatr,

-Ektopik tiroit dokusu (örn. lingual veya tiroglossal kanal kistinde fonksiyone tiroit dokusu) araştırması,

-Retrosternal guatr,

-Agenezi, hemiagenezi,

-Cerrahi sonrası bakiye tiroit dokusunun değerlendirilmesi,

-Boyun ve üst mediasten kitlelerinin incelenmesi,

-Tiroit nodüllerinin fonksiyonel durumunun değerlendirilmesi,

-Tirotoksikoz ayırıcı tanısı (diffüz veya nodüler toksik guatr, tiroidit ve ekzojen tiroit hormon alımı),

-Tiroidit tanı ve takibi,

-Hipotiroidi (doğumsal veya edinsel),

-T3 süpresyon testi sırasında.

\section{Metodoloji}

\subsection{Kullanılan radyofarmasötikler}

\subsubsection{Radyoaktif iyot}

Radyoaktif iyot seçici olarak tiroit tarafindan yakalanıp organifiye olması ve tiroit hormon yapımına katılması nedeniyle tiroit fonksiyonları hakkında fizyolojik ve klinik bilgi sağlar; bu nedenle ideal bir fizyolojik radyofarmasötiktir. ${ }^{123}$ Iyot $\left({ }^{123} \mathrm{I}\right)$ ve ${ }^{131} \mathrm{Iyot}\left({ }^{131} \mathrm{I}\right)$ klinik olarak kullanılan radyoizotoplardır. İyodun hızlı emilimi, tiroide hızlı alınımı ve organifikasyonu nedeniyle, radyoaktivite tiroit bezinde dakikalar içinde saptanabilir ve folliküler lümene 20-30 dakikada ulaşır. İyodun tiroit bezinde yirmi dört saatin üzerinde progresif alım artışı görülür. Zemin aktivitenin temizlenmesi ve yüksek hedef/ zemin aktivitenin sağlanması için radyoaktif iyodun oral alımı ile görüntüleme arasında ${ }^{123} \mathrm{I}$ için $2-6$ saat, ${ }^{131} \mathrm{I}$ için ise 48-72 saat beklenir. Radyoaktif iyodun fizyolojik tutulum alanlarını tükürük bezleri, mide ve daha az oranda koroid pleksus oluşturur. Böbrekler ve gastrointestinal traktus atılım yollarıdır (Ziessman ve ark., 2006).

\subsubsection{1. ${ }^{131}$ Iyot}

${ }^{131}$ İyot'un fiziksel yarı ömrü sekiz gündür. Gama radyasyonu görüntülemeye izin verirken, beta radyasyonu tedavide kullanılır. Negatron (beta-) $(\mathrm{E}=0,606 \mathrm{MeV})$ bozumuna uğrar. Yaydığ1 364 keV'lik gamma fotonu günümüzde kullanılan gama kamera görüntülemesi için optimal değildir. Rutin tiroit sintigrafisinde kullanılmaz. Klinik endikasyonları substernal guatr ve tiroit kanserinde sinırlı olup substernal guatr görüntülemesinde $50 \mu \mathrm{Ci}$ oral verilir.

\section{Dozimetri}

Yüksek enerjili beta emisyonu ve uzun fiziksel yarı ömrü nedeniyle rölatif olarak fazla radyasyon verir $(1 \mathrm{rad} / \mu \mathrm{Ci})$.

\subsubsection{2. ${ }^{123}$ Iyot}

${ }^{123}$ Iyot benign tiroit hastalıklarında görüntüleme ve uptake çalışmalarında ideal bir radyofarmasötiktir. Siklotron ürünü olması nedeniyle her an elde edilememesi dezavantajıdır. ${ }^{123}$ Iyot elektron yakalama ile bozunur ve yarı ömrü 13,2 saat- tir. Ana gama emisyonunun enerjisi $159 \mathrm{keV}$ olup gama kamera görüntülemesi için optimaldır. Görüntüleme ve uptake incelemeleri oral alımdan sonra 2-6. ve 24. saatlerde yapilır.

\section{Dozimetri}

Görüntüleme ve uptake çalışmaları için aynı doz kullanılir (0,2-0,5 mCi) (Joyce ve Swihart, 2011). $200 \mu \mathrm{Ci}(0,2 \mathrm{mCi})$ ${ }^{123}$ I uygulanmasıyla tiroidin aldiğ 1 doz 1,5-2,6 rad (cGy) dır. Daha düşük radyasyon dozimetrisi nedeniyle rutin tiroit sintigrafisinde ${ }^{131}$ I'e oranla daha yüksek dozlarda uygulanabilir (50 $\mu \mathrm{Ci}$ ye karşın 200-400 $\mu \mathrm{Ci}$ ) ve daha yüksek kalitede imaj elde edilir (Ziessman ve ark., 2006).

\subsubsection{3. ${ }^{99 \mathrm{~m}}$ Tc-Perteknetat}

Düşük maliyeti ve ${ }^{99}$ molibden- $/{ }^{99 \mathrm{~m}} \mathrm{Tc}$ jeneratör sisteminden üretimiyle her an elde edilebilir olması tiroit sintigrafisinde radyoaktif iyoda alternatif olmuştur. $140 \mathrm{keV}$ 'lik gama enerjisi ile gama kamerada görüntüleme için idealdir. Partiküler emisyonu yoktur ve fiziksel yarı ömrü 6 saattir. Radyoaktif iyodun oral kullanımına karşın ${ }^{99 \mathrm{~m}}$ Tc Perteknetat intravenöz uygulanır. İyot gibi tiroit tarafindan yakalanır ancak organifiye olmaz ve tiroit hormon yapımına katılmaz. Tiroit görüntüleme, enjeksiyon sonrası pik aktivitenin olduğu 20-30. dakikada gerçekleştirilir. Partiküler radyasyonunun olmaması ve kisa yarı ömrü nedeniyle, rutin tiroit sintigrafisinde ${ }^{123}$ I'ten daha yüksek dozlarda (3-5 mCi) uygulanabilir. Yüksek foton akımı yüksek kalitede görüntü sağlar. $5 \mathrm{mCi}$ uygulamada tiroidin aldığı doz 0,6 rad (cGy) dır (Ziessman ve ark., 2006 ).

\section{Hangi radyofarmasötik kullanılmalı?}

Rutin tiroit sintigrafisinde kolay elde edilebilirliği, görüntüleme ve radyasyon dozimetre özelliklerinden dolayı ${ }^{99 \mathrm{~m}} \mathrm{Tc}$ perteknetat kullanılır. ${ }^{123}$ İyot, ${ }^{99 \mathrm{~m}} \mathrm{Tc}$ perteknetata oranla daha yüksek enerjisinden ve perteknetat uygulaması sonrası sıklikla izlenebilen mediastinal kan havuzu aktivitesi nedeniyle substernal tiroit bezi görüntülemesinde avantaj sağlar. ${ }^{131}$ Iyot kötü imaj kalitesi ve yüksek radyasyon dozimetresi nedeniyle rutin tiroit sintigrafisinde tercih edilmez. Uzun yarı ömrü geç dönemde görüntülemeye izin verirken hedef/zemin aktivite oranının artmasına olanak sağlayarak substernal guatr ve tiroit kanseri görüntülemesinde avantaj sağlar; ancak bu endikasyonlarda ${ }^{123} I^{\prime}$ ün avantajlarından ötürü çoğu kez ${ }^{123} I^{\prime}$ tercih edilir. ${ }^{131}$ İyot yüksek enerjili beta emisyonundan dolayı Graves hastalığ 1 , toksik nodüller ve tiroit kanseri radyoterapisinde oldukça başarı ile kullanılmaktadır (Ziessman ve ark., 2006 ).

\section{Enstrümantasyon/Ekipman}

\subsection{Gama kamera}

Gama kamera nükleer tıbbın bel kemiğini oluşturan bir buluş olup, teknesyum ve iyot gibi gama emisyonuna sahip radyonüklitlerin görüntülemesinde kullanılır. Gama kameradaki dedektörün ön kısmında yer alan kolimatör süzgeç görevi ile istenmeyen foton saçılmalarını azaltarak rezolüsyonun artmasını sağlar. ${ }^{99 m} \mathrm{Tc}-$ ve ${ }^{123} \mathrm{I}$ için düşük enerjili kolimatör kullanılır. Yüksek enerjiye sahip ${ }^{131}{ }^{1}$ 'in görüntülenmesi için kalın kurşun septalara sahip yüksek enerjili kolimatöre ihtiyaç vardır. Tiroit bezinin görüntülenmesi için daha optimal olan kolimatör pinhole (iğne deliği) kolimatördür. Gama kameraya yerleştirilmiş koni şekline sahip olup hasta tarafında dar bir açıklığı vardır (Şek. 1). 


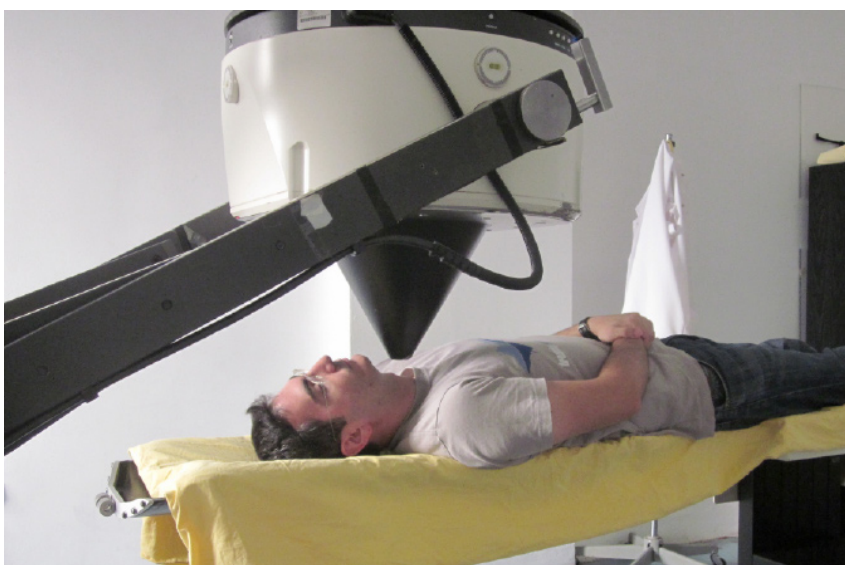

Şek. 1. Pinhole kolimatör ile tiroit sintigrafisi uygulamasında görüntüleme pozisyonu

Bu özel kolimatör küçük yapıları büyütür ve yüksek rezolüsyonlu görüntü elde edilmesini sağlar. Pinhole kolimatör ${ }^{99 m}$ Tc veya ${ }^{123} \mathrm{I}$ ile görüntülemede tipik kullanılan kolimatördür (Joyce ve Swihart, 2011).

\subsection{Uptake probu}

Tiroidin genel olarak basitçe fonksiyon ölçümü tek kristalli sayım cihazı olan tiroit uptake probu ile ölçülebilir. Bu basit işlem, hastaya doz verilmeden önce birinci günde standart ölçümü ile başlar. Doz verildikten sonra 4. ve 24. saatlerde hastanın boyun, uyluk bölgesi (hasta zemin aktivite) ve oda zemin aktivitesi ölçümleri yapılır (Joyce ve Swihart, 2011). Tiroidin radyoaktif iyot uptake (RAIU) oranı aşağıdaki formül yardımıyla manüel ya da otomatik olarak hesaplanabilir.

$$
\% \text { RAIU }=\frac{\text { Boyun aktivitesi }(\text { sayım } / \mathrm{dk}) *}{\text { Verilen doz kapsül }(\text { sayım } / \mathrm{dk}) * *}
$$

*(zemin aktivite düzeltilmiş)

**(zaman ve zemin aktivite düzeltilmiş)

\subsection{SPECT, PET ve hibrit görüntüleme}

Nükleer Tipta, 1980'lerden beri kullanılan tek foton emisyon bilgisayarlı tomografi (SPECT) ve 1990' larda klinik kulanıma giren PET inceleme teknikleri daha öncesinde alışılagelmiş iki boyutlu planar görüntülemenin yanında, radyotrasör dağılımı ve lokalizasyonunun üç boyutlu olarak değerlendirilmesine olanak verir. SPECT ve PET kameralarına Bilgisayarlı Tomografi (BT)'nin eklenmesiyle oluşturulan hibrit cihazlar, ek olarak atenüasyon düzeltmesi ve lezyonun doğru olarak yerini belirlemeyi sağlarlar. SPECT/BT ve PET/ BT günümüzde rutinde benign ve malign hastalıkların değerlendirilmesinde yaygın olarak kullanılmaktadır (Joyce ve Swihart, 2011). PET/ manyetik rezonans (MR) ise yakın gelecekte moleküler ve anatomik füzyon görüntülemede önemli yer edinecek hibrit modalite gibi gözükmektedir.

\section{Hasta hazırlığı ve özel durumlar}

Gebelik sorgulanır (varsa kontrendikedir). Gebeliğin 1012. haftalarından itibaren fetal tiroit radyoiyot konsantre etmeye başlar. Radyoaktif iyot plasentayı geçer ve tedavi dozları sonrası fetal tiroidin aldığı ciddi radyasyon sonrası fetusta hipotiroidi hatta kretenizm oluşur.

Radyoaktif iyot süte geçer. Uzun yarı ömründen dolayı ${ }^{131}$ I' in tanisal ve tedavi uygulamaları sonrası emzirme kesilir. ${ }^{123}$ I'ten sonra emzirmenin 2-3 gün, bazı kaynaklarda ise tümüyle kesilmesi önerilir (Değer ve ark., 2004). ${ }^{99 \mathrm{~m}}$ Tc perteknetat ile yapılan işlemler sonucu ise 24 saat (min 4 saat) emzirmenin kesilmesi önerilir (Değer ve ark., 2004; Ziessman ve ark., 2006).

\section{Tablo 1. Sakınılacak yiyecekler}

\begin{tabular}{l} 
Yiyecek \\
\hline İyotlu tuz, kaya tuzu \\
Deniz ürünleri (balıklar dahil) \\
Süt, dondurma, peynir ve yoğurt \\
İşlenmiş et ürünleri (Salam, sosis vb.)(Taze et yenebilir) \\
Tuzlu yiyecekler (cips, tuzlu bisküvi, kraker, çerezler) \\
Hazır kahve \\
Çay ve limonata \\
Konserve sebze ve meyveler \\
Ispanak, marul ve bazı sebzeler \\
Kırmızı biber içeren yiyecekler \\
Parlak kırmızı renkli hazır gıdalar (iyotlu boya içerebilir) \\
\hline
\end{tabular}

${ }^{99 \mathrm{~m}} \mathrm{Tc}$ perteknetat tiroit sintigrafisi öncesi açlık gerekmez ve diyet k1sitlamas1 yoktur. ${ }^{131} \mathrm{I}$ ve ${ }^{123} \mathrm{I}$ tiroit sintigrafisinde ise, yaklaşık 2-3 hafta süreyle düşük iyotlu diyet uygulanır (Tablo 1) (Yüksel ve ark., 2001). Emilimin etkilenmemesi için hastaya, radyoiyot alımından 3-4 saat önce ve 1 saat sonra katı g1da yenmemesi gerekliliği, su içilebileceği söylenir.

Verilen radyofarmasötiğin tiroit bezinde tutulumunu etkileyen ilaçların kullanılıp kullanılmadığı sorulur. Bu ilaçların, test öncesi uygun sürelerde kesilmesi gereklidir (Tablo 2, Yüksel ve ark., 2001; Ziessman ve ark., 2006).

Tabloda yer almayan adrenokortikotropik hormonlar, adrenal steroitler, monovalan anyonlar (perklorat), penisilin de azalmış tutuluma neden olabilir. Konjestif kalp yetmezliği, renal yetmezlik ve boyuna radyoterapi uygulamaları da tiroit bezinde azalmış tutulum sebepleri arasındadır.

Tablo 2. Kesilmesi gereken ilaç / bileşikler

\begin{tabular}{lc} 
İlaç ve Bileşik Adı & Süre \\
\hline Propiltiourasil & 1 hafta \\
Perklorat & 1 hafta \\
Sülfonamidler & 1 hafta \\
Tapazole & 1 hafta \\
Tiyosiyanat & 1 hafta \\
Penisilin & 1 hafta \\
Nitratlar & 1 hafta \\
Antihistaminikler & 1 hafta \\
Antikoagulanlar & 1 hafta \\
İyot solüsyonları (topikal solüsyonlar, saç boyaları) & $2-9$ hafta \\
Bazı öksürük şurupları ve vitamin preperatları & 2 hafta \\
İyotlu ilaçlar (Amiadoron vb.) & Haftalar-aylar \\
Triiyodotironin & $(3-6$ ay) \\
Tetraiyodotironin & 2 hafta \\
İntravenöz konstrast ajanlar & $4-6$ hafta \\
Oral kolesistografik ajanlar & $1-3$ hafta \\
Bronkografi & $2-3$ hafta \\
Miyelografi & $6-12$ ay \\
\hline
\end{tabular}


Yukarıda bahsedilen tiroidte azalmış tutulum sebepleri yanı sıra iyot eksikliği, gebelik, tiroit hormonları veya anti tiroit ilaç bıraktırılması sonrası oluşan rebound durumları ve lityum kullanımlarında da artmış radyofarmasötik tutulumun olacağı akılda bulundurulmalıdır (Ziessman ve ark., 2006).

Sintigrafik inceleme, mutlaka biyopsi uygulamasından önce yapılmalıdır. Eğer biyopsi yapılmışsa yara iyileşmesi süresince (1-2 hafta) beklenmelidir.

$\mathrm{T}_{3}$ süpresyon testinde, tiroit sintigrafisi çekimi, 7-10 gün süre ile $3-4 \times 25 \mu \mathrm{g}$ tri-iodotironin'in oral alımından sonraki gün yapılır.

Tiroit sintigrafisi her zaman hastanın klinik öyküsü, tiroit muayenesi, serum tiroit fonksiyon testleri ve tiroit ultrasonografi (USG) bulguları 1şı̆̆ında değerlendirilmelidir. Tiroit sintigrafisi tek bir imajda tüm bezi gösterir ve fizik muayene bulguları ile görüntüdeki anomalilerin karşılaştırılmasına olanak sağlar. Özellikle küçük doku ve organların görüntülenmesinde kullanılan özel bir sistem olan pinhole (iğne deliği) kolimatör (Şek. 1), paralel delikli kolimatör sistemine oranla daha iyi imaj rezolüsyonu sağlar (1-2 cm'e karşın 5 $\mathrm{mm})$. Bez ve nodülün anatomik ve fonksiyonel korelasyonu için radyoaktif işaret kaynağı (122 keV lik ${ }^{57} \mathrm{Co}$ veya $\left.{ }^{99 \mathrm{~m}} \mathrm{Tc}\right)$ kullanılır.

\section{Tiroit kanserinde sintigrafik çalışma}

Tiroit kanseri hücreleri, genelde normal tiroit dokusuna oranla hipofonksiyonel olduklarından radyoaktif iyodu daha düşük derecede alırlar. $\mathrm{O}$ nedenle malign nodüller, rutin tiroit sintigrafisinde soğuk olarak görüntülenirler. Kanserli tiroit hücresinde alımı artırmak için tiroit stimulan hormon (TSH) stimülasyonu gerekir. TSH stimülasyonu iki şekilde sağlanabilir. İlkinde, total tiroidektomi ve radyoaktif iyot tedavisi sonrası hasta hipotiroidik duruma getirilerek TSH düzeyinin artması sağlanır. TSH nın endojen stimülasyonu için, tiroit hormon preparatlarının kesilmesi gerekir (Tetraiyodotironin için 4-6 hafta; Triiyodotironin için 3 hafta). Radyoaktif iyot uygulaması için serum TSH düzeyinin $>30$ IU olması gerekir. Alternatif olarak tiroit hormonu kesilmeden rekombinant TSH (rTSH) ile stimülasyon gerçekleştirilebilir. Düşük iyot içerikli diyet uygulanması da iyot havuzunu azaltıcı, alımı arttırmaya yardımcı olur.

\section{1. ${ }^{131} \mathbf{I} y o t$}

Tiroit kanseri (differansiye) hastalarında tüm vücut görüntülemede rutinde oral 5-10 $\mathrm{mCi}{ }^{131}$ I kullanılır. Görüntüleme standart olarak 48. ve 72. saatlerde yapılır, gerekirse geç görüntü alınabilir. Eğer iyot tedavisi öncesi görüntüleme yapılıyorsa tedavi etkinliğini azaltacak olası tiroit stunning (sersemleme) ini engellemek için $2 \mathrm{mCi}$ gibi daha düşük dozlar kullanılır. Endojen TSH stimülasyonu için rTSH (thyrogen) kullanılacaksa alım \% 50 azalacağından doz 4 mCi'ye çıkarılır. Rekombinant TSH 0,9 mg intramüsküler ardışık iki gün verilir. Üçüncü günde radyoaktif iyot uygulanır. Görüntüleme ${ }^{131}$ I kullanıldığında 5. gün, ${ }^{123}$ I kullanıldığında ise 4. günde yapılır. Serum tiroglobulini 5. günde ölçülür.

\section{2. ${ }^{123}$ İyot}

${ }^{123}$ İyot oral olarak 1,5-2 mCi verilir. Stunningin olmamas1, imaj kalitesinin yüksek olması ve çalışmanın 24. saatte tamamlanması ${ }^{131}$ I'e avantajlarını oluşturur. Vakaların \% 93' ünde tedavi sonrasi ${ }^{131}$ Iyot sintigrafisi ile uyumlu bulgular elde edildiği bildirilmiştir (Shanker ve ark., 2002). Daha erken görüntülemeden dolayı, ${ }^{123}$ I ile daha düşük düzeyde tümoral doku dedekte edildiğine dair yayınlar bulunmaktadır (Sarkar ve ark., 2002; Ma ve ark., 2005).

\section{Klinik endikasyonlar}

Tiroit sintigrafisi uzun yıllardır çeşitli tiroit hastalıklarının tanısında kullanılmaktadır. Günümüzde diğer görüntüleme modalitelerinin kullanıma girmesi ve tiroit nodüllerinde tanısal perkütan aspirasyon biyopsisinin yoğun kullanımı ile eskiye oranla daha az tercih edilir olmuştur. Tiroit sintigrafisi bezin fonksiyonunu göstermesi nedeniyle, birçok hasta için hali hazırda çok değerli bilgiler vermektedir.

\section{Normal tiroit sintigrafisi}

Normal tiroit bezi kelebek şeklindedir ve lateral loblar tiroit kartilajı boyunca uzanır. Lateral loblar önde krikoid kartilajı altında istmusla bağlıdır. Tiroit bezinin sintigrafik görüntüsü hastadan hastaya çok farklılık gösterebilir. Sağ lob soldan genelde büyüktür. Lateral lobların boyutları alt ve üst kutup arası 4-5 cm genişliği ise 1,5-2 cm dir. Piramidal lob istmustan veya komşuluğundaki lobdan hiyoit kemiğe doğru uzanım gösterir. Radyofarmasötik normal tiroit bezinde homojen dağılım gösterir. Lateral lobların orta ve medial kesimleri bazen doku kalınlığına bağlı olarak artmış aktivite dağılımı gösterebilirler (Şek. 2). İstmus aktivitesi çok değişken olup bazılarında çok belirginken bazılarında hiç görüntülenmez. Normal erişkinlerde ince piramidal lob sıklıkla gözükmez. Tükürük bezleri rutin ${ }^{99 \mathrm{~m} T c}$ perteknetat incelemesinde görüntülenip, normalde tiroit bezinden hafifçe daha düşük aktivite gösterirler. ${ }^{123}$ I sintigrafisinde daha geç görüntüleme yapıldığından genelde tükürük bezleri izlenmez. Perteknetat sintigrafisinde ${ }^{123}$ I sintigrafisine oranla daha yüksek düzeyde zemin aktivite izlenir. Özafagus aktivitesi her iki ajanla görüntülemede problem olabilir. Genelde görüntülemede boyun hiperekstansiyonda olduğunda orta hattın solunda izlenir ve hastaya su içirilerek ek bir görüntülemeyle, temizlendiğinde, aktivitenin özafagusa ait olduğu doğrulanır. Tiroidin normal iyot uptake oranları 4-6. saatlerde \% 5-15, 24. saatte ise \% 10-30 aralığındadır (Joyce ve Swihart, 2011).

\section{Tiroit sintigrafisinde patolojik bulgular}

Tiroit sintigrafisinin sistematik değerlendirilmesinde tiro-

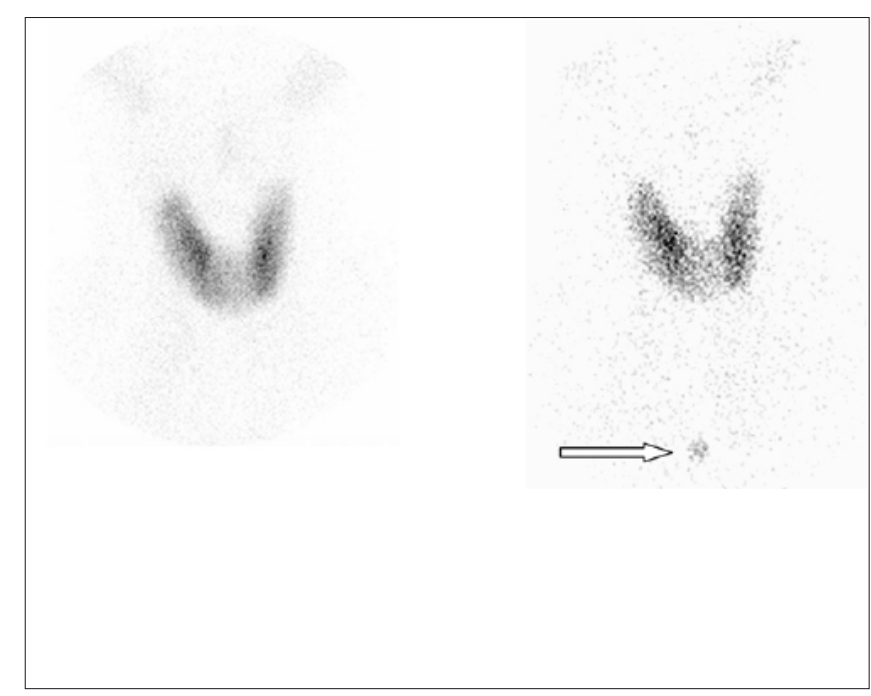

Şek. 2. Normal tiroit sintigramı; ok: sternal çentik 
idin konumu, boyutu, aktivitesi ve nodül içeriği yer alır.

\subsection{Tiroit nodülüi}

Tiroit nodülleri sık rastlanan patolojiler olup, görülme sıklığı kadınlarda erkeklere oranla daha fazladır. Yaşla birlikte hem benign hem de malign nodüllerin görülme sıklığı artar. Nodülün benign-malign ayırımı çoğu kez klinik problem oluşturur. Nodülün, genç hasta ve erkek cinsiyette olması veya yakın zamanda büyümesi malign olma şüphesini artırır. Çok sayıda nodül varlığı malignite riskini azaltır. Graves hastalarında nodül tespit edildiğinde özellikle radyoaktif iyot tedavisi öncesinde incelemek gerekir.

Baş boyun bölgesine veya mediastene radyasyon uygulaması özellikle çocuklarda artmış tiroit kanseri insidansı ile ilişkilidir. On yıllar önce asemptomatik büyük timus bezi, tonsil, adenoid veya akne tedavisinde radyoterapi kullanıl1yordu.

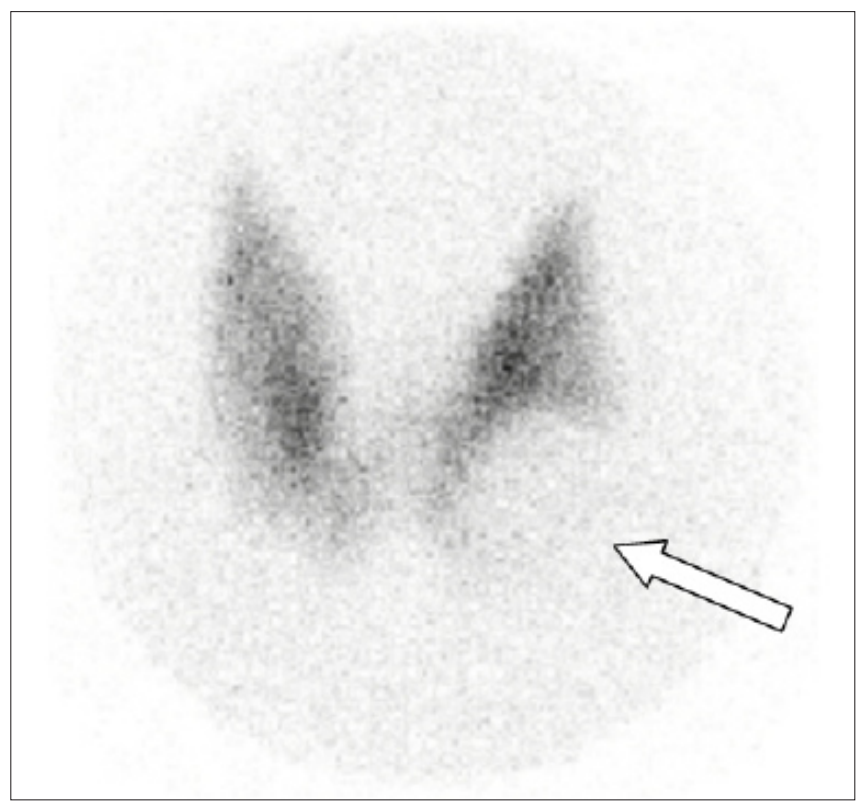

Şek. 3. Sol tiroit lobu alt kutupta hipoaktif nodül görünümü.

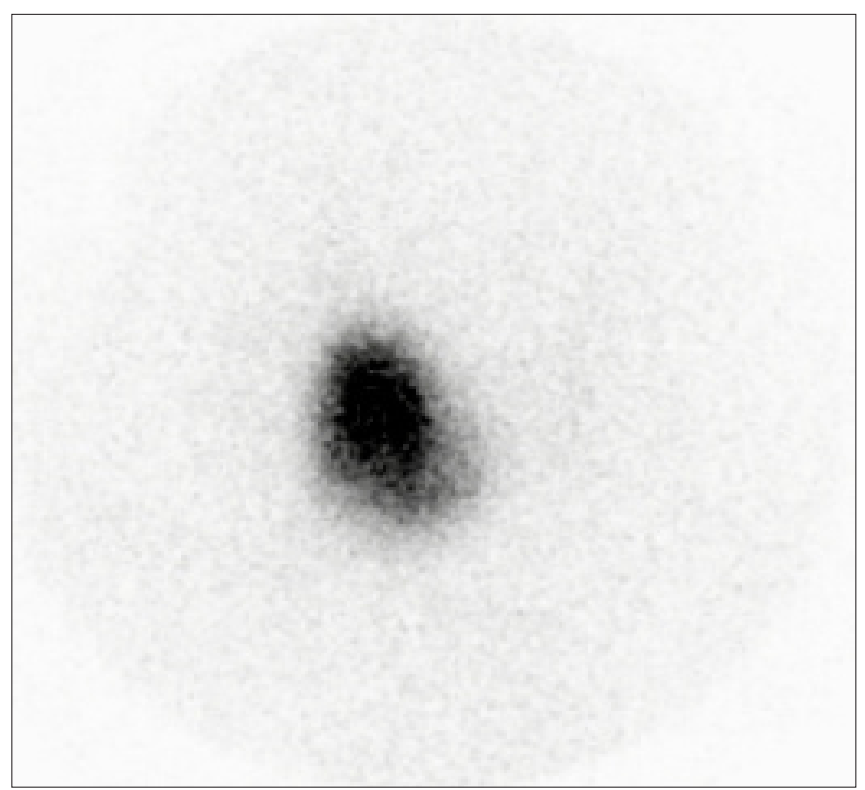

Şek. 4. Toksik nodül. Bezin kalan kesimleri süprese görünümde

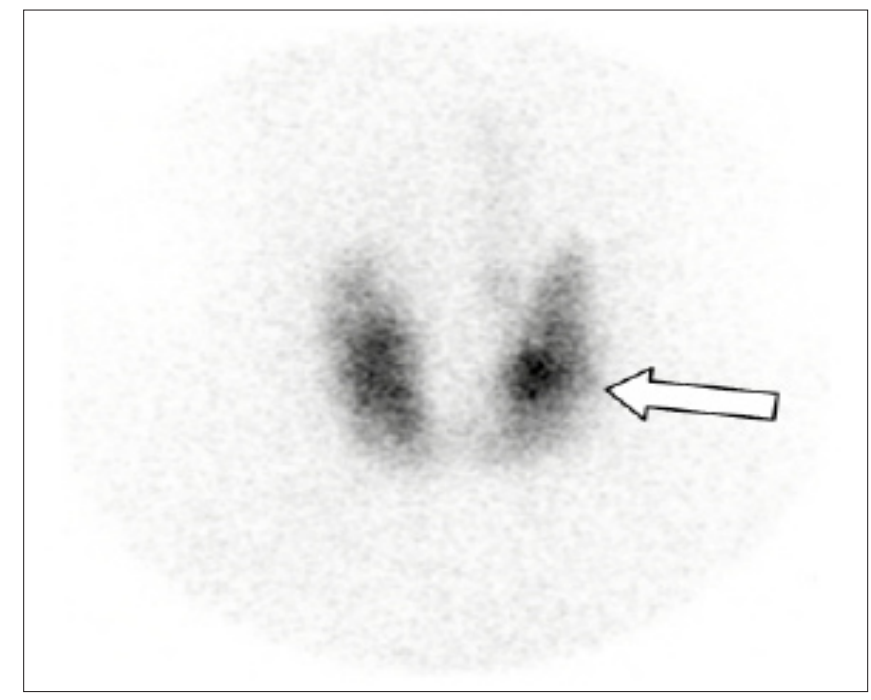

Şek. 5. Ilık nodül

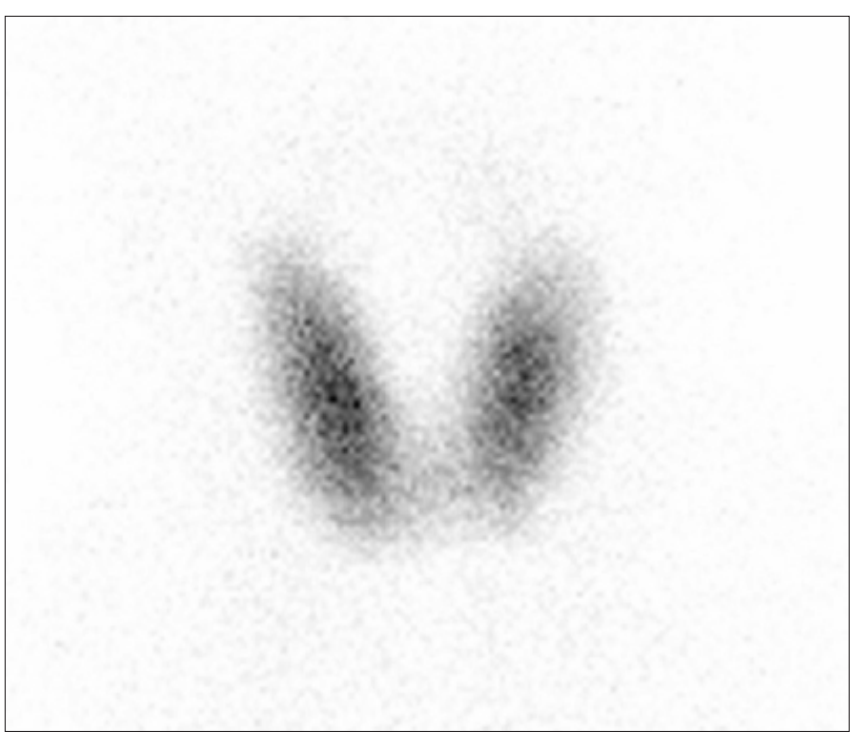

Şek. 6. Indeterminate (belirsiz) nodül; USG de sağ lob alt kutup bölgesinde $1,5 \times 1,8 \mathrm{~cm}$ lik nodüle rağmen, sintigrafide nodül ile uyumlu görünüm mevcut değil

Genel olarak 10-50 radlik radyoterapi, tiroit kanseri insidansını artırır. Hiroşima, Nagazaki ve Çernobil'den yay1lan radyasyon sonrasında tiroit kanseri insidansı artmıştır. 1500 rada kadar olan radyasyon maruziyetinde tiroit nodülü ve kanseri insidansı artar. Ortalama latent periyodu yaklaşık beş yıldır. 1500 radın üzerinde muhtemelen doku harabiyetine bağlı risk azalır. Malign tümörlerin tedavisinde kullanılan yüksek doz daha çok hipotiroidizme neden olur. Tiroit sintigrafisi ile nodül tanısı konmaz. Sintigrafide görülen sıcak veya soğuk odaklar birçok patolojiye bağlı olabilir (tiroidit veya skar gibi). Nodül tanısı tiroidin fizik muayenesi ya da bir anatomik görüntüleme modalitesi (USG, BT veya manyetik rezonans görüntüleme gibi) ile tespit edilebilir.

Tiroit sintigrafisi ile fizik muayene veya anatomik bir görüntüleme ile tespit edilen nodüllerin fonksiyonel durumu belirlenir. Tiroit nodülleri sintigrafik olarak soğuk (hipoaktif; normal tiroit dokusuna oranla hipofonksiyone) (Şek. 3); s1cak (hiperaktif; nodül dışı glandın süpresyonuna neden olan hiperfonksiyone) (Şek. 4); 1lık (nodül dışı dokuda süpresyon yapmaksızın komşu dokuya oranla artmış aktivite) (Şek. 5) 
ya da indeterminate (belirsiz; palpe edilen ancak sintigrafide görüntülenemeyen) olarak tanımlanır (Şek. 6). Indeterminate nodüllerin yönetimi soğuk nodüller gibidir. Bazı otörler, yukarıda tanımlanan belirsiz nodülleri de 1lık nodül sınıflamasinda kabul etmektedirler (Joyce ve Swihart, 2011). Sintigrafi ayrıca çok sayıda nodülün varlığını da gösterebilir (Şek. 7). Sintigrafik bulgular malignite yönünden rölatif bir risk değerlendirilmesi yapılmasını sağlar. Tiroit sintigrafisine göre soğuk ve indeterminate nodüllerde tiroit kanseri riski \% 15$20 \mathrm{iken}$, bu oran çok sayıda nodül varlığında $\% 5$, sıcak nodül varlığında ise \% 1'in altındadır.

Özellikle son dekatta tiroit USG ve ince iğne aspirasyon biyopsisi (İ̈AB) nin artan kullanımı ile tiroit sintigrafisinin, nodüllerin karakterizasyonundaki kullanımı belirgin azalmıştır (Joyce ve Swihart, 2011). Buna rağmen tiroit sintigrafisi spesifik durumlarda hala önemli role sahiptir. Yeni revize edilen Amerikan Tiroit Birliğinin (ATA) kılavuzunda, tiroit sintigrafisi, nodülü olan $(>1 \mathrm{~cm})$ ve beraberinde düşük TSH değerlerine sahip hastaların başlangıç incelemesinde önerilmektedir. Eğer nodül hiperfonksiyone ise hastaya hipertiroidi tedavisi verilir ve sitolojik değerlendirme gerekmez. Sinırda yüksek serum TSH düzeylerinin dahi tiroit nodülünde artmış malignensi riski ile ilişkili olduğu bildirilmiştir (Boelaert ve ark., 2006; Cooper ve ark., 2009).

$\mathrm{Bu}$ kılavuzda tiroit sintigrafisi ( ${ }^{123} \mathrm{I}$ ile), aynı zamanda İ̇AB'nde folliküler neoplazm düşünülen olguların değerlendirilmesinde de önerilmektedir. Hiperaktif (sıcak) bir nodül varlığında çoğunlukla benign bir etiyoloji düşünülürken, otonom fonksiyonel nodül görülmüyorsa lobektomi veya total tiroidektomi önerilmektedir (kanıt düzeyi C) (Cooper ve ark., 2009). Tiroit sintigrafisinin özellikle 1-1,5 cm'in altında nodülleri değerlendirirken pinhole görüntülemede dahi rezolüsyonunun sınırlı olabileceği akılda tutulmalıdır.

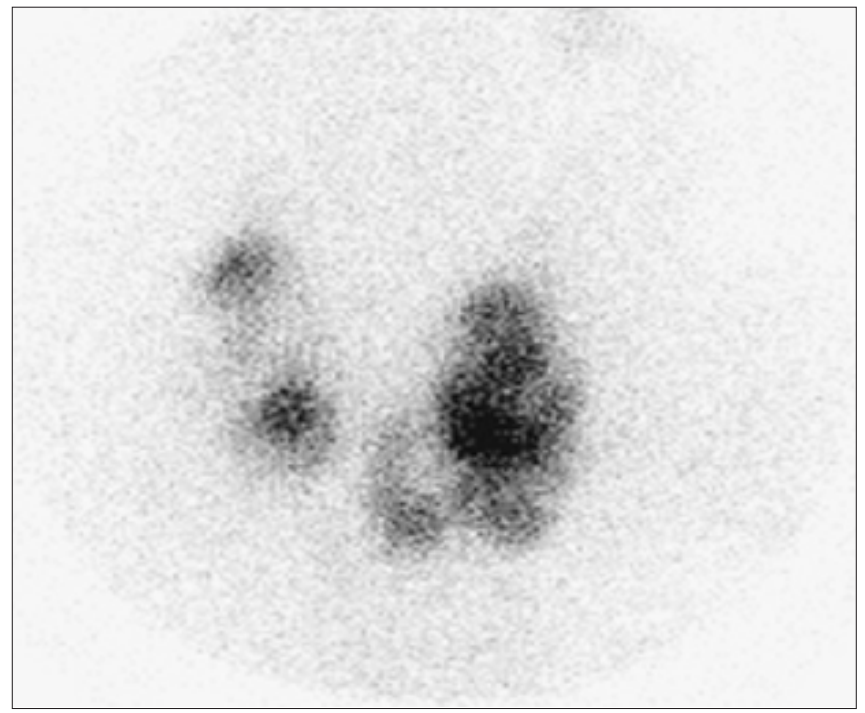

Şek. 7. Hiperaktif multinodüler bez

\subsubsection{Soğuk (hipoaktif nodül) nodül}

Tiroit nodüllerinin \% 85-90'ı tiroit sintigrafisinde soğuktur (Şek. 3). Soğuk nodül, basit kist, kolloid nodülleri, tiroidit, hemoraji, nekroz ve amiloid veya hemakromatoz gibi infiltratif hastalıklar dahil benign etiyolojiye bağlı olabilir. Bununla birlikte soğuk nodüle sahip hastaların önemli bir kısmında (\% 5-35 oranında) malign etiyoloji bulunmakta olup, tespit edil- diğinde USG ve gerektiğinde biyopsi ile ileri inceleme gerekir. Hipoaktif nodüller primer (papiller, folliküler, anaplastik, medüller, Hurthle, lenfoma) ya da metastatik (akciğer, meme, melanoma, gastrointestinal, renal) tiroit malignitelerine bağlı olabilir. Boyut artışı gösteren ya da dominant nodüllerin rölatif olarak artmış risk göstermeleri nedeniyle ileri incelemeleri gerekir.

\subsubsection{Sıcak ve Ilık nodüller}

Nodül içindeki radyoaktif iyot alımı nodülün fonksiyonunu gösterir. Fonksiyone bir nodülün malign olma olasıllı̆g düşüktür. Sicak (hiperaktif) nodül terimi sintigrafik olarak yüksek aktivite gösteren aynı zamanda da nodül dışı dokuda süpresyona neden olan nodüller için kullanılmalıdır (Şek. 4). Ekstranodüler doku süprese değilse nodül, 1lık nodül olarak adlandırılmalıdır (Şek. 5).

Sıcak nodüllerin sebebi toksik adenomatöz nodüllerdir. Illk nodüllerin sebebi ise otonom hiperfonksiyone adenomlar olup, tirotoksikoz oluşturmak için yeterli hormon üretmezler ve bu nedenle TSH süprese değildir. Ilık nodül otonom olmayan hiperplastik doku veya kötü fonksiyon gösteren doku tarafindan sarılan normal fonksiyone doku nedeniyle olabilir. Ayırım tiroit süpresyon testi ile yapılabilir. Otonom nodüller süprese olmazlar. Bununla birlikte günümüz pratiğinde süpresyon testine nadiren ihtiyaç duyulur.

Hipertiroidiye genelde $2,5-3 \mathrm{~cm}$. den büyük nodüller neden olurlar; daha küçük nodüllere sahip bazı hastalarda subklinik hipertiroidi gelişebilir (süprese TSH beraberinde normal $\mathrm{T}_{4}$ düzeyi). Küçük otonom nodüllerin bir kısmı takipte değişmezken bazıları geriler ya da kaybolabilir; bu nedenle bu nodüller geçmişte klinik olarak takip edilirlerdi. Düşük regresyon insidansından ve subklinik hipertiroidili hastalarda görülen istenmeyen etkilerden (kemik mineral kaybı vb.) dolayı nodüllerin erken evrelerde tedavisi giderek artmaktadır. Toksik nodüllerin tedavisinde radyoaktif ${ }^{131} \mathrm{I}$ sık tercih edilen tedavi seçeneğidir. Hiperfonksiyone dokuya selektif olarak internal radyasyon verilirken, baskılanmış olan nodül dışı doku korunmuş olur.

Normal dokunun süprese olması nedeniyle tedavi sonrası hipotiroidi insidansı oldukça düşüktür. Nodülün başarılı tedavisinden sonra baskılanmış doku fonksiyonunu geri kazanır. Lokal semptomlar veya kozmetik sorunlar varsa cerrahi, genelde lobektomi uygulanabilir (Ziessman ve ark., 2006 ).

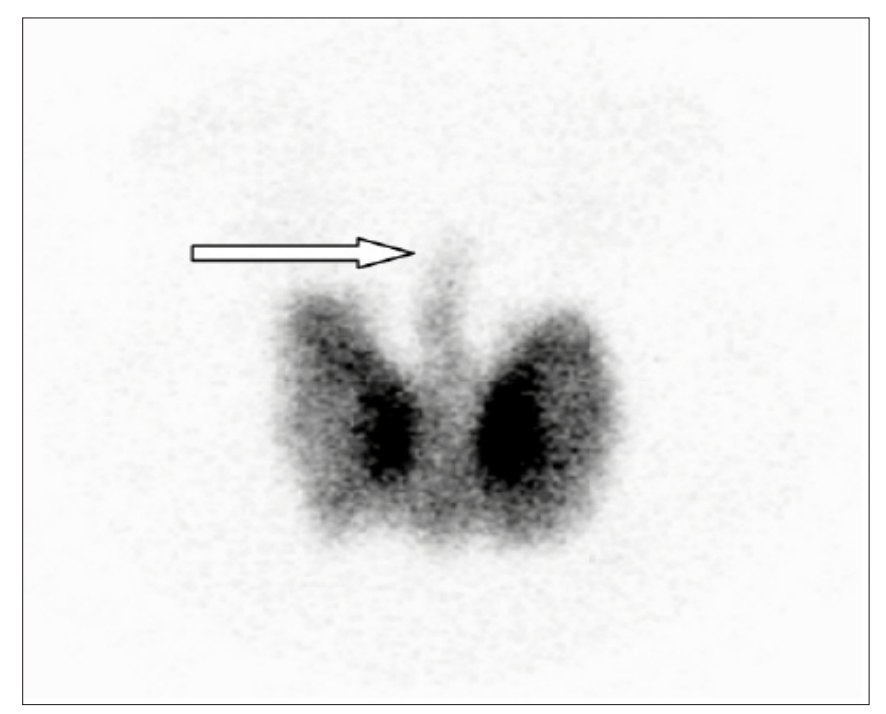

Şek. 8. Graves hastalı̆̆ı, ok: piramidal lob 


\subsubsection{Indeterminate (Belirsiz) nodül}

Palpe edilen veya ultrasonografik olarak $>1 \mathrm{~cm}$ tespit edilen nodülün tiroit sintigrafisinde sıcak ya da soğuk olarak aktivitesi belirlenemiyorsa indeterminate nodül olarak adlandırılır (Şek. 6). Normal glandüler aktivite ile çevrelenen posterior yerleşimli bir nodül normal aktivitedeymiş gibi gözükebilir. Belirsiz nodüllerin yönetimi soğuk nodüller gibi olmalıdır.

\subsubsection{Uyumsuz nodül}

Nodül perteknetat görüntülemede sıcakken radyoiyot görüntülemede soğuk olarak görüntülenebilir; çünkü ${ }^{99 m}$ Tc perteknetat tiroit tarafindan yakalanır ancak organifiye olmaz. $\mathrm{Bu}$ uyumsuzluk yaklaşık olarak perteknetat sintigrafisinde saptanan sıcak nodüllerin yaklaşık \% 5 'inde görülür. Bazı tiroit kanserlerinde yakalama olmasına rağmen organifikasyon olmadığından, perteknetat sintigrafisinde saptanan soliter sıcak nodül, radyoiyot ile doğrulanmayıncaya kadar fonksiyone kabul edilmemelidir. Uyumsuz nodüllerin yaklaşık \% 20'si malign bulunmuştur. Tiroit sintigrafisinde rutin olarak 99m Tc perteknetat kullanımı uyumsuz nodül varlığında dezavantaj oluşturmaktadır (Ziessman ve ark., 2006 ).

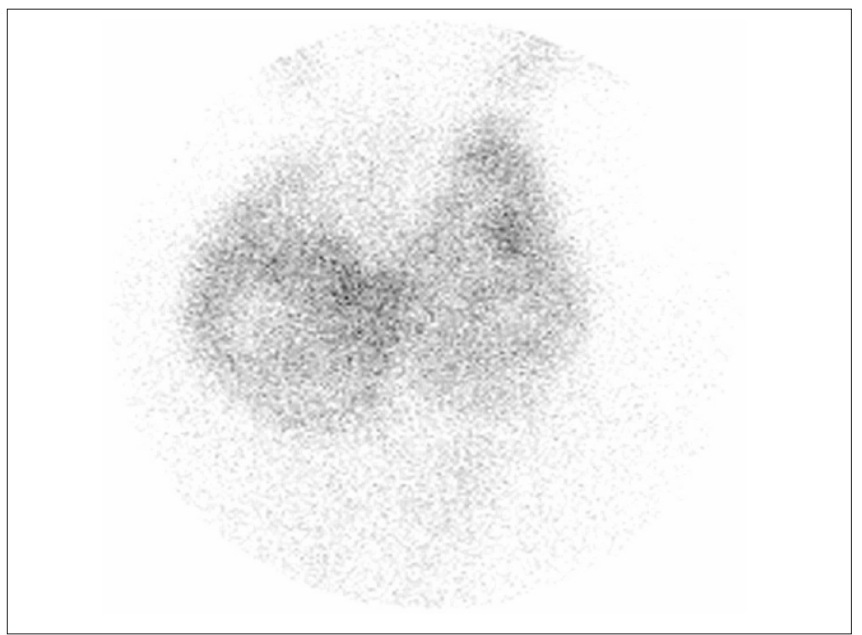

Şek. 9. Hipoaktif multinodüler guatr

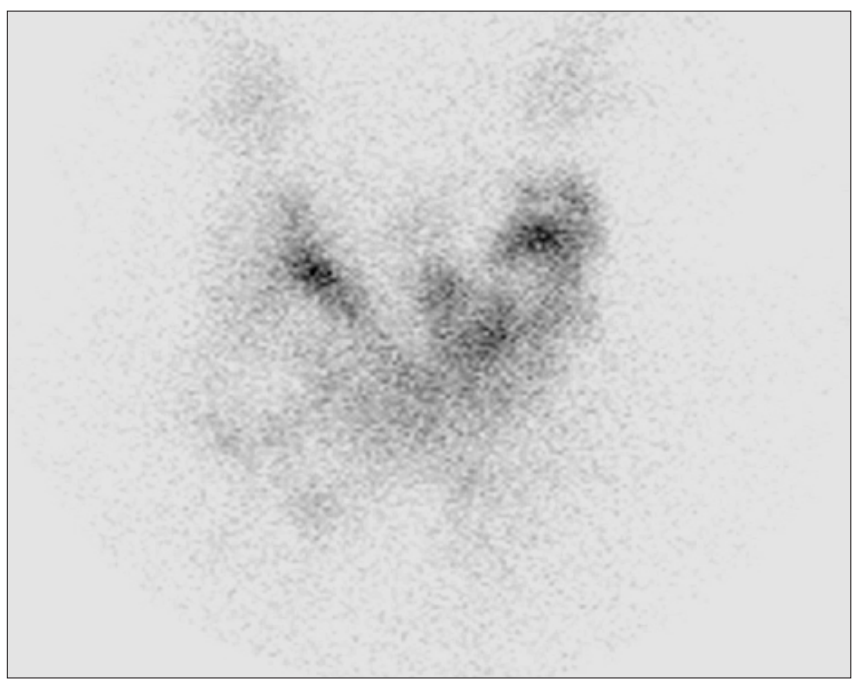

Şek. 10. Hiperaktif-hipoaktif multinodüler guatr

\subsection{Hipertiroidizm}

Tiroit uptake ve sintigrafisinin hipertiroidi tanı ve tedavisinde önemli role sahip olduğu kanıtlanmıştır.

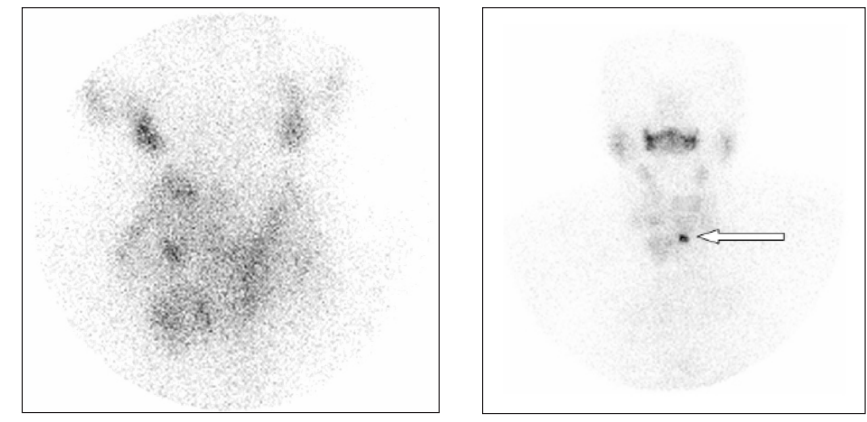

Şek. 11. Substernal tiroit; ok: sternal çentik

Uptake çalışmaları hipertiroidizmin ana sebebini ayırt etmede primer rol oynar. Çok düşük tiroit uptake değerleri subakut tiroidit, postpartum tiroidit veya amiadoron toksisitesinde saptanırken; toksik nodüler hastalıkta genelde normal ya da yüksektir (\% 20-40); Graves hastalığında ise yüksektir ( $>\%$ 50). Toksik nodüler guatr ve Graves'de saptanan yüksek aktivitenin paterni de tiroit sintigrafisi ile incelenebilir. Homojen aktivite dağılımı Graves hastalığında izlenirken (Şek. 8), heterojen patern nodüler hastalığın sintigrafik bulgusudur (Şek. 7).

\subsection{Guatr}

Terminolojik olarak guatr tiroit bezinin büyümesidir; ancak çoğu kez sebebi ile birlikte ifade edilir (Toksik nodüler guatr, kolloidal guatr veya diffüz toksik guatr gibi).

\subsection{Graves hastalığı ve multinodüler toksik guatr}

Yeni tanı almış tirotoksikozu olan bir hastada fizik muayene ile genelde Graves hastalığında görülen diffüz guatr ile multinodüler toksik bez ayırıcı tanısı yapılabilir. Tiroit sintigrafisi ayırımı yapmaya yardımcıdır. Toksik nodüler guatrda palpe edilen ya da ultrasonografik olarak görüntülenen nodüllere karşılık gelen hiperaktif nodüller izlenirken, nodül dışında kalan doku süpresedir (Şek. 7). Graves hastalığında ise bez homojen olarak diffüz artmış aktivite gösterir. İstmus, sağ veya sol lob superiorundan yükselen piramidal lob, Graves hastalığında genelde iyi görüntülenir (Şek. 8).

\subsection{Kolloidal nodüler guatr}

İyot eksikliği olan bölgelerde endemik olarak görülür. Hastalardaki nodül formasyonunun patogenezinde iyot eksikliğine bağlı hiperplaziyi takiben fonksiyone nodüllerin oluşumu yer alır. Oluşan bu nodüllerde daha sonra hemoraji, nekroz ve kolloid gölleri oluşur. Bu sürecin tekrarı zamanla bezin büyümesine yol açarak fonksiyon göstermeyen kolloid nodülleri dominant histopatolojik görüntüyü oluşturur. Benign multinodüler kolloidal guatrın tipik sintigrafik bulgusu çeşitli boyutlarda soğuk alanlar içeren heterojen aktivite dağılımıdır (Şek. 9,10).

\subsection{Substernal guatr}

Substernal guatrların çoğu tiroidin mediasten içine uzantısıdır. Büyüdüklerinde dispne, disfaji veya stridor gibi semptomlara neden olabilirler. Çoğu asemptomatik olup, BT'de ön mediastinal kitle olarak tesadüfen saptanırlar. Radyoiyot sintigrafisi ile kitle orijininin tiroidal olduğu doğrulanır. Perteknetat sintigrafisi, yüksek mediastinal kan havuzu aktivitesi nedeniyle substernal guatr görüntülemede uygun değildir. Doku ve kan havuzu temizlendikten sonra geç görüntülemeye olanak vermesi substernal görüntülemede ${ }^{131}$ I'in avantaj1- 


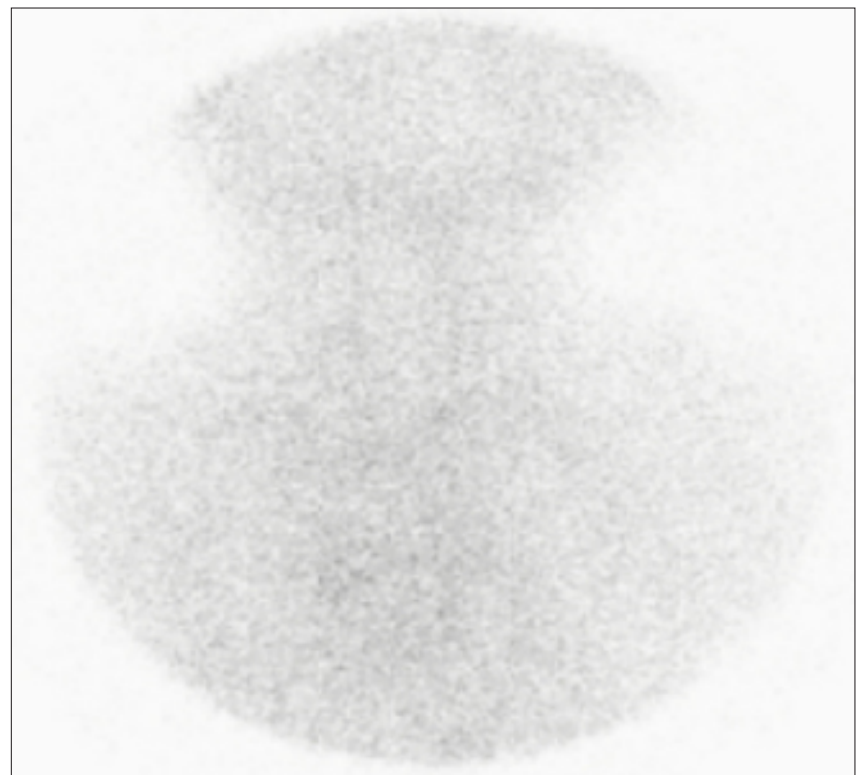

Şek. 12. Agenezi

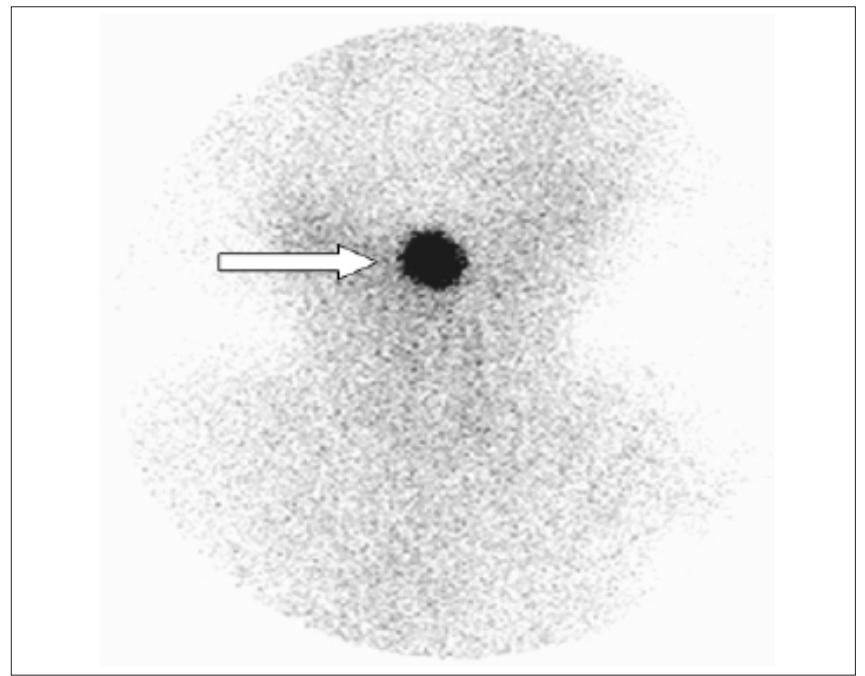

Şek. 13. Lingual tiroit

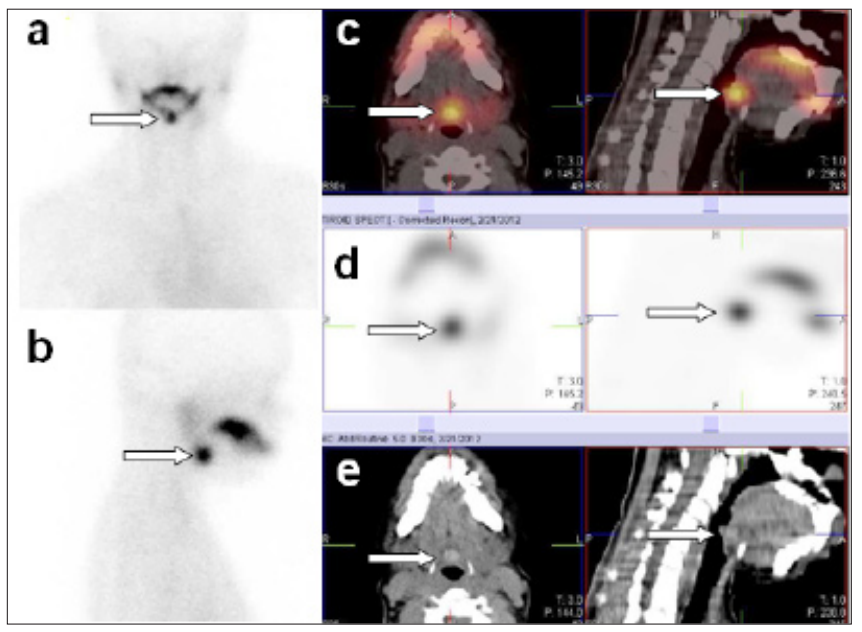

Şek. 14. Lingual tiroid. 40 yaşında hipotiroidi semptomlarıyla başvuran hastada ( $\mathrm{TSH}>100)$ tiroid doku aktivitesi, planar sintigrafik görüntülemede $(\mathrm{a}, \mathrm{b})$ oral tükürük aktivitesinden net ayırt edilemezken SPECT/BT incelemede dil kökünde tiroid dokusu ve aktivitesi net olarak ayırt edilebiliyor (c: füzyon görüntü, d: SPECT ve e: BT). nı oluşturur. Substernal guatrda iyot alımı azalır ve mümkün olan en yüksek hedef/zemin aktiviteye ulaşmak arzulanır. Bazen 24-48 saat sonra görüntüleme gerekebilir. Substernal guatrda ${ }^{123} \mathrm{I}$ 'den çok ${ }^{131} \mathrm{I}$ 'in kullanılmasının temelinde ${ }^{123}$ I'ün sternum tarafından atenüe olması yer alır; ancak ${ }^{123}$ I ile atenüasyon sadece \% 10-20 oranındadır. Çoğu vakada ${ }^{123} \mathrm{I}$, daha iyi imaj kalitesi ve hastaya daha düşük radyasyon vermesi nedeni benzer bilgi verebilir. Çoğu vakada ${ }^{123}$ I, daha iyi imaj kalitesi ve daha düşük radyasyon dozu ile benzer bilgi verir. Substernal guatr ararken tiroit glandının olağan servikal yerleşimi her zaman görüntülenmelidir. Çoğu substernal tiroit, glandın servikal kısmı ile devamlılık gösterirken (Şek. 11), bazı hastalarda servikal ve substernal tiroit dokuları sadece fibröz bir bant ile bağlantılıdırlar.

\subsection{Hipotiroidizm, ektopik tiroit dokusu}

Tiroglossal duktus, dil kökünde foramen caecumdan tiroide uzanır. Migrasyonun yeterli olmadığı durumda, yenidoğanda lingual veya üst servikal bölgede tiroit dokusu şeklinde izlenebilir.

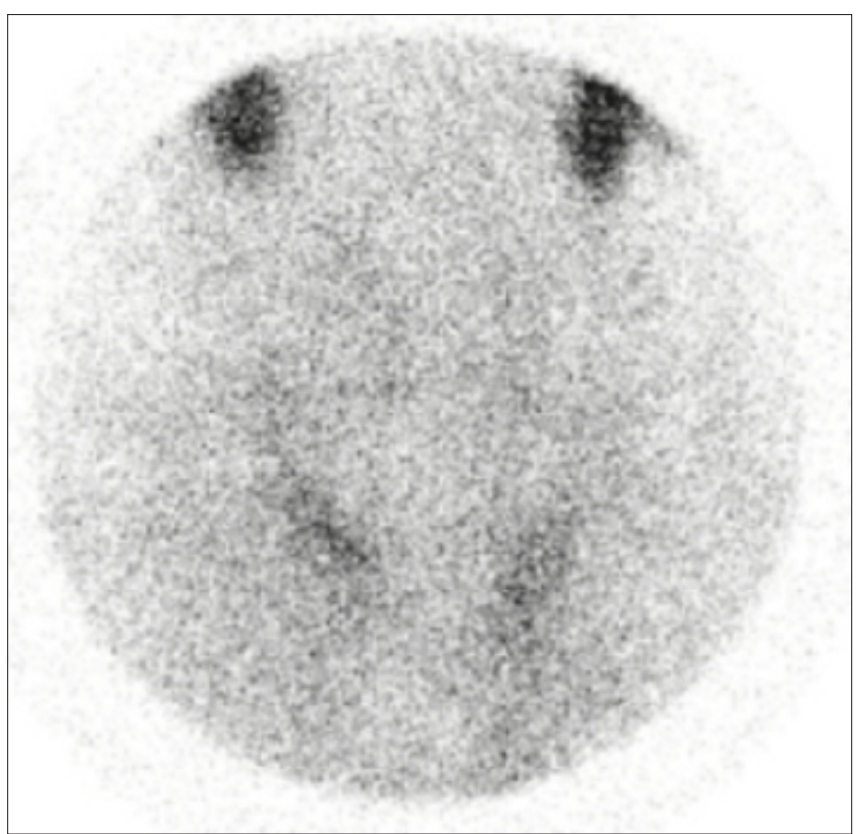

Şek. 15. Subakut tiroidit

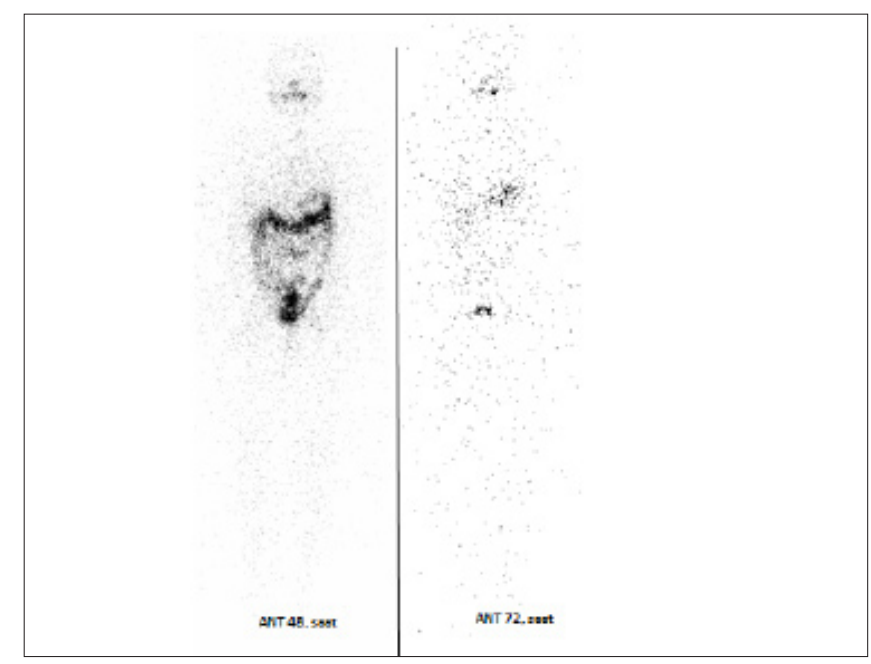

Şek. 16. Normal ${ }^{131}$ I Tüm vücut sintigrafisi . Anterior 48 ve 72 saat görüntüleri 

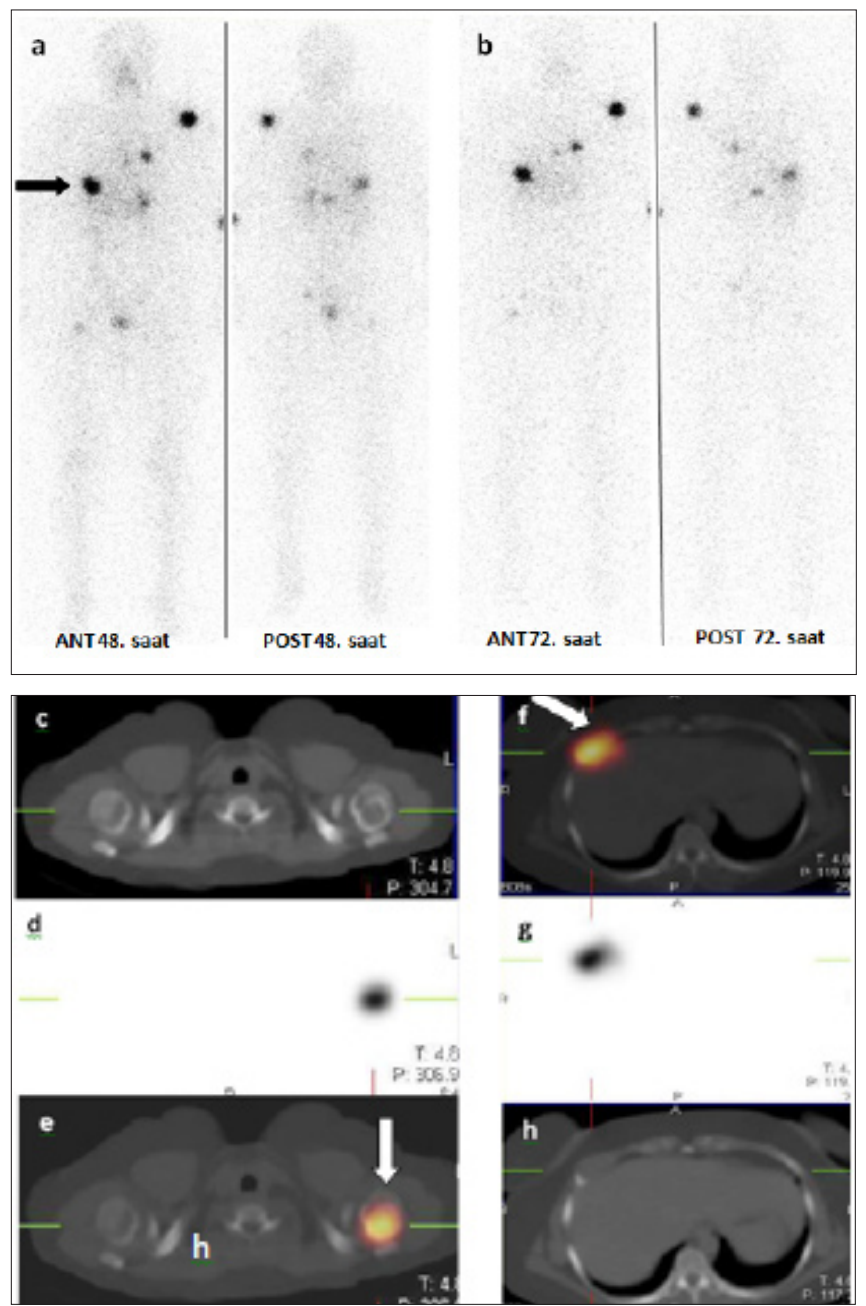

g

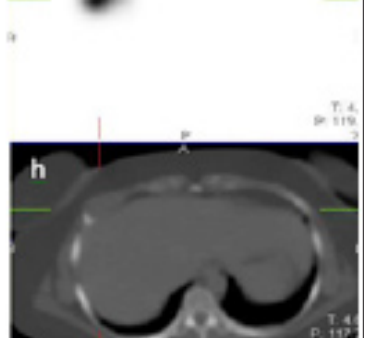

Şek. 17. Folliküler tiroid kanseri tanılı bir hastada, takiplerinde ${ }^{131}$ I Tüm vücut sintigrafisinde multifokal metastatik kemik lezyonları (a, b de planar tüm vücut; c (BT), d (SPECT), e (SPECT/BT füzyon) aksiyel kesitlerde sol humerus başında medüller düzeyde (e, ok) ve planardan (a, ok) karaciğer (KC) metastazı gibi gözüken ancak üç boyutlu görüntülemede kostal litik metastaza (f: SPECT/BT füzyon, ok) ait ${ }^{131} \mathrm{I}$ aktivite odağı izleniyor.

Çocuklarda semptomsuz veya obstrüktif semptomlarla birlikte orta hatta kitle şeklinde kendini gösterir. Ektopik tiroit dokusu, mediastinal (substernal guatr) ya da pelvik/ovaryan (struma ovari) olabilir.

\section{Sintigrafi}

Tiroit USG'sinde ve sintigrafisinde bez görüntülenemiyorsa agenezi düşünmek gerekir (Şek. 12). Tiroit bezi tiroit USG'sinde görüntülenirken, sintigrafide beze ait aktivite izlenmiyorsa TSH reseptör bloklayıcı antikorlar etiyolojik faktör olabilir.

Lingual tiroidin tipik görüntüsü beklenen servikal alanda aktivite yokluğu ile birlikte dil kökünde fokal ya da nodüler karakterde aktivite akümülasyonudur (Şek. 13, 14). Lingual tiroidlerin sıklıkla fonksiyonu kötüdür. Lateral tiroit kalıntıları sıklıkla hipofonksiyoneldir. Bununla birlikte fonksiyon gösterebilir, hiperfonksiyone olabilir hatta tiroidin adeno kanserini içerebilir. Fonksiyone ektopik tiroit dokusu aksi ispat edilinceye kadar metastatik olarak kabul edilmelidir ( $\mathrm{Zi}$ essman ve ark., 2006 ).

\subsection{Subakut tiroidit}

Hipertiroidi varlığında tiroit bezi süprese görünümdedir (Şek. 15). Toparlanma fazında tiroidin görünümü değişken olup, hastalığın ciddiyeti ve yayılımı ile ilişkilidir. Sintigrafide heterojen aktivite dağılımı, bölgesel hatta fokal hipofonksiyone alanlar şeklinde olabilir.

\subsection{Kronik tiroidit (Hashimoto tiroiditi)}

Sintigrafik bulgular çok değişkendir. Sürecin erken döneminde sintigrafi normal olabilir ancak genelde bezin diffüz büyümesi söz konusudur. Bez aktivitesi tümüyle heterojen olabilir ve palpe edilen nodül yokken fokal soğuk alanlar olabilir. Piramidal lob Hashimoto tiroiditinde sıklıkla görülür.

\subsection{Akut tiroidit}

Nadir görülen bu patolojinin sık sebebi süpüratif bakteriyel enfeksiyondur. Tiroit tipik olarak büyümüş ve hassastır. Fokal apseler sintigrafik olarak soğuk görüntülenir. Riedel struma tiroiditin sık olmayan bir formu olup, bezin tamamı ya da bir kısmı fibrotik doku ile yer değiştirmiştir. Fibröz doku alanında aktivite izlenmez.

\subsection{Tiroit kanseri}

Tüm vücut ${ }^{131}$ I sintigrafisi uzun zamandır iyi differensiye papiller ve folliküler tiroit kanserinde kullanılmaktadır (Şek. 16, 17). S1klıkla takipte, tedaviye yanıtın değerlendirilmesinde ve total tiroidektomi sonrası radyoaktif iyot tedavisi öncesi uygulanır. Medüller tiroit kanseri ve anaplastik karsinom iyot konsantre etmediklerinden bu kanserlerde kullanımının yeri yoktur. Tüm vücut ${ }^{131} \mathrm{I}$ sintigrafisinde hasta hazırlığı gerekir. Maksimal endojen TSH cevabına ( $>30 \mathrm{U} / \mathrm{ml}$ ) na ulaşmak için genel yaklaşım olarak hormon replasman tedavisi 4-6 hafta süreyle kesilir.

Hipotiroidizm semptomlarını azaltmak için, hastalarda bazen daha kısa etkili triiodotironin $\left(\mathrm{T}_{3}\right)$ kullanılır ve sintig-

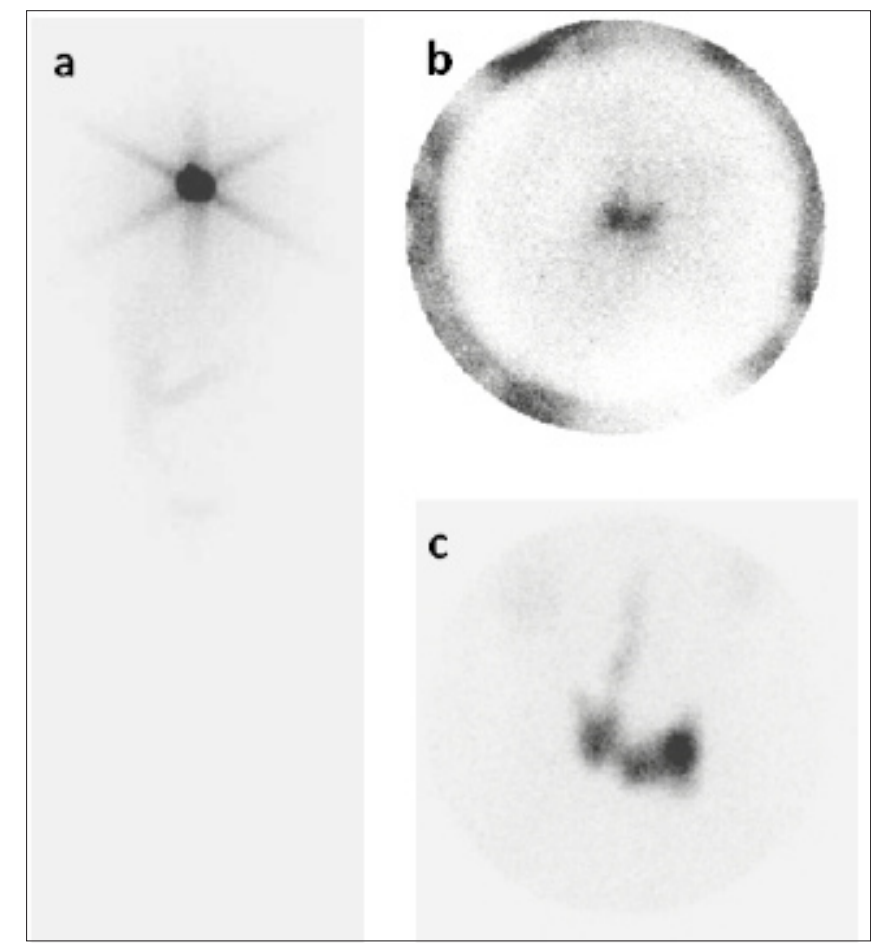

Şek. 18. Star artefakt, a: ${ }^{131}$ I tüm vucüt sintigrafisi, b:Pinhole kolimatör ile ${ }^{131} \mathrm{I}$ tiroid görüntüleme, c: Pinhole kolimatör ile ${ }^{99 \mathrm{~m}}$ Tc perteknetat tiroid sintigrafisi 
rafi öncesi 2 hafta bıraktırılır. ${ }^{131}$ I ile görüntüleme tipik olarak tanısal doz uyguladiktan 48 saat sonra yapilır. Maksimum TSH stimülasyonunda serum tiroglobulin (Tg) düzeyleri de bakılır. ${ }^{123}$ I için tüm vücut görüntüleme 24 . saatte alınır.

Tiroidektomi sonrası, servikal ve mediastenin değerlendirilmesine engel olacak, tiroit yatağında yüksek intensitede aktivite olması (star artefakt) beklenen bir bulgu değildir. Artefaktın sebebi yüksek enerjili fotonların kolimatörden septal penetrasyonudur (Şek. 18a). Pinhole kolimatörde septa olmadığından boyundaki yüksek intensitedeki aktiviteyi daha iyi çözer (Şek. 18b). Postoperatif hastada boyunda yüksek aktivitenin sebebi rezidüel normal doku ya da tiroit kanserine bağlı olabilir (Şek. 18c).

\section{Diğer tiroit görüntüleme radyofarmasötikleri}

\section{1. ${ }^{201}$ Tl ve ${ }^{99 m}$ Tc Sestamibi}

Her iki radyofarmasötik de spesifik olmayan tümör görüntüleme ajanlarıdır. Benign ya da malign durumlarda tutulum gösterebilirler. ${ }^{99 \mathrm{~m}} \mathrm{Tc}$ sestamibinin tiroit kanserinin saptanmasında genel olarak duyarlılığı \% 36-89, özgüllüğü ise \% 89-100 arasındadır (Haugen and Lin, 2001). Sestamibi özellikle nodal metastazların saptanmasında duyarlı olup, akciğer metastazlarında ve boyunda rezidüel tiroit dokusunun gösterilmesinde düşük duyarlılığa sahiptir. ${ }^{201} \mathrm{Tl}$ ' un primer tiroit kanseri metastazlarında duyarlılığı \% 35-96, özgüllüğü ise \% 94-97 arasındadır. ${ }^{201} \mathrm{Tl}$ ' in en iyi sonuçları, servikal ve mediastinal lenf nodu metastazlarında verdiği gösterilmiştir (Brendel ve ark., 1988; Shiga ve ark., 2001). Her iki ajan da tiroit kanserinin başlangıç tanısında yaygın olarak kullanım alanına sahip değillerdir. Bazıları, tiroit kanseri takip görüntülemesinde, ayrıca normal ve benign doku ile, tümör dokusunun ayırt edilmesinde önermektedir. Görüntüleme öncesi tiroit hormon replasmanının kesilmemesi avantajdır. Bu yaklaşım daha çok yüksek Tg düzeyleri ve beraberinde negatif iyot görüntüleme olduğunda daha çok kabul görmekle birlikte ${ }^{18}$ F-florodeoksiglukoz (FDG) Pozitron Emisyon Tomografisi (PET) bu endikasyonun yerini hızlıca almıştır.

\section{2. ${ }^{18}$ F florodeoksiglukoz (FDG )}

${ }^{18} \mathrm{~F}$ FDG nin iyi differensiye tiroit kanserleri metastazlarında duyarlılığı yüksek değildir ( $\% 70)$; radyoiyot tüm vücut taraması negatif hastalarda duyarlılık daha yüksektir (\% 85). Tek başına PET’ in \% 78 tanısal doğruluğuna karşın,

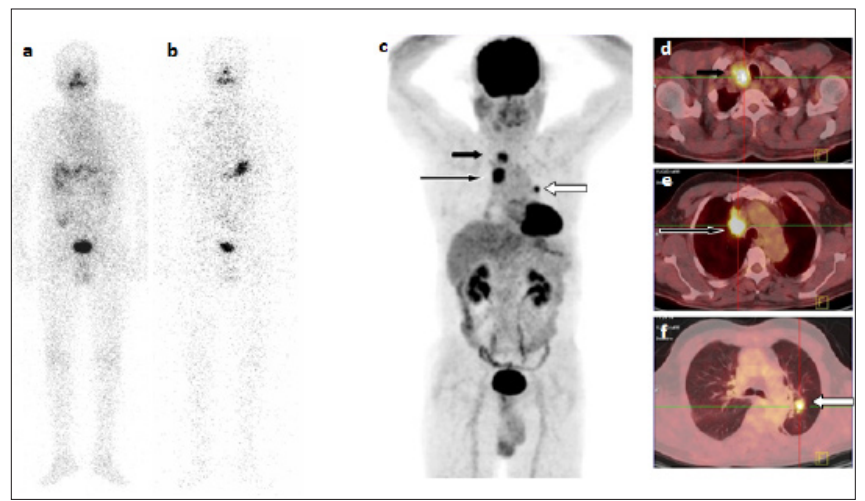

Şek. 19. Papiller tiroit kanseri tanılı hastada takipte ${ }^{131}$ İyot negatif (anteriordan a: 48. saat; b: 72. saat görüntüleri) ve ${ }^{18} \mathrm{~F}$ - FDG pozitif görüntüleme (c-f) bulguları (tiroglobulin=72 ng/mL; sağ servikal, mediastinal (c,d,e, oklar) ve solda hipermetabolik akciğer nodülleri (f, ok) izleniyor.

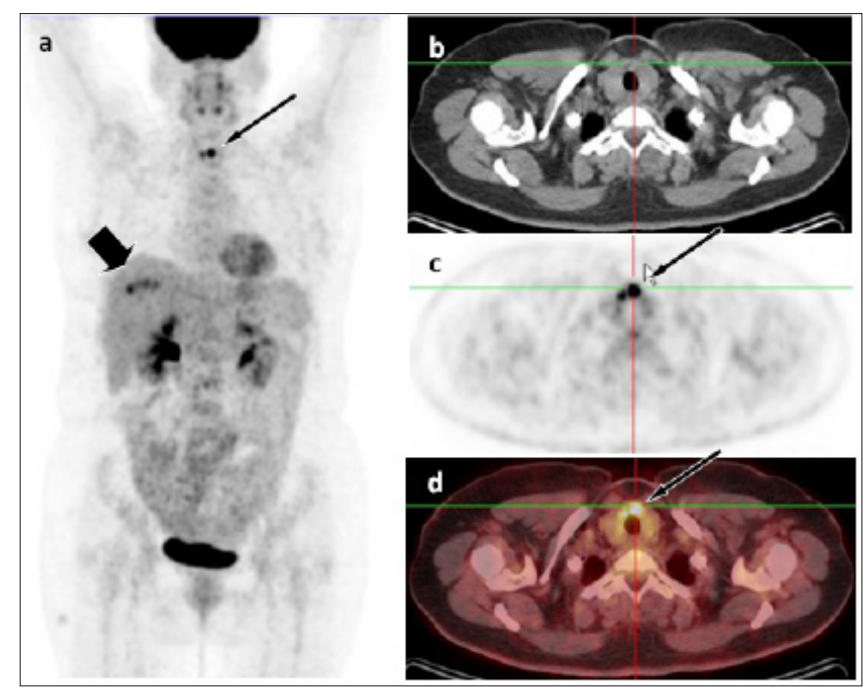

Şek. 20. İnsidental FDG pozitif tiroit nodülü. Karaciğerde kitle (a, kalın ok) nedeniyle biyopsi yapılan hastanın histopatolojik olarak nöroendokrin tümör tanısı konması üzerine ${ }^{18} \mathrm{~F}$ PET-BT ile primer tümör odağ1 araştırılması sırasında tiroidte fokal hipermetabolik odak (a,c,d, ince ok); saptandı. İİA sonucu papiller tiroit kanseri idi.

PET/BT nin doğruluğu \% 93’tür (Palmedo ve ark., 2006).

Tiroit kanser görüntülemesinde rutinde kullanılmaz. Ana endikasyon negatif ${ }^{131}$ I tüm vücut görüntülemesi, beraberinde artmış Tg (özellikle Tg>10 ng/ml) durumlarıdır. Bu hastalarda tümör daha yüksek dereceye dedifferensiye olmuştur. $\mathrm{Bu}$ hastaların çoğunda metastaz yerinde fokal 18F-FDG akümülasyonu vardır (Şek. 19).

Tümör dedifferensiasyon derecesinin yüksek olması FDG alım gücünü artırır. Tümör lokalizasyonu cerrahi veya tedavi yanıtının değerlendirilmesine olanak sağlar.

Diğer onkolojik tümörlerin değerlendirilmesi nedeniyle yapılan tüm vücut ${ }^{18} \mathrm{~F}$-FDG PET görüntülemede tiroit bezinde bazen fokal FDG akümülasyonu izlenir. Bu bulgu genelde tiroit patolojisini gösterir. Hastalarda \% 50'ye varan oranlarda tesadüfi olarak tiroit kanseri tanısı konur (Şek. 20). Tiroit kanseri dışında diğer fokal FDG akümülasyon nedenleri, metastatik tiroit kanseri, benign folliküler adenoma ve tiroidittir. Diffüz artmış bez metabolik aktivitesi, tiroidit ve Graves hastalığında görülür.

Medüller tiroit kanserinin preoperatif evrelemesinde ${ }^{18} \mathrm{~F}$ FDG PET genelde kullanılmaz. Cerrahi sonrası artan kalsitonin ya da CEA düzeyi durumlarında endikasyonu vardır. Duyarlılık \% 79-99, özgüllük \% 79 dolayındadır (Diehl ve ark., 2001). Bazı çalışmalarda kalsitonin düzeyleri ile lezyon saptanabilirliği arasında anlamlı bir ilişki olmadığı öne sürülmektedir (Diehl ve ark., 2003). Bu verilerin tersine, bir başka çalışmada PET' in en çok kalsitonin düzeyi >1000 ng/ml olduğunda yararlı olduğu (Ong ve ark., 2007) kalsitonin düzeyi $<500 \mathrm{ng} / \mathrm{ml}$ ise PET yararının sınırlı olacağı öne sürülmektedir (Abraham ve Schöder, 2011).

\section{3. ${ }^{131} \mathrm{I} /{ }^{123}$ I metaiodobenzilguanidin (MIBG)}

Bazı medüller tiroit kanserlerinde ${ }^{131} \mathrm{I}$ veya ${ }^{123} \mathrm{I}$ Metaiodobenzilguanidin (MIBG) akümülasyonu görülür; ancak duyarlılık düşüktür ( \% 30). MIBG kromofin hücrelerinin nörosekratuar depo veziküllerinde lokalize olur. Yumuşak doku metastazları, kemik metastazlarından daha iyi görüntülenir. 
Düşük duyarlılık nedeniyle medüller tiroit kanserinin rutin incelemesinde kullanılmaz (Ziessman ve ark., 2006).

\section{4. ${ }^{111}$ Indium somatostatin reseptör sintigrafisi}

Medüller tiroit kanseri nöroektodermal bir tümördür. Ancak birçok nöroektodermal tümörlerin aksine tiroidin medüller tiroit kanseri tespitinde In-111 somatostatin reseptör sintigrafisinin duyarlılığı düşüktür $(<\% 50)$.

\subsection{Diğer tiroit fonksiyon testleri}

Günümüzde bu klasik farmakolojik intervansiyonlar sıklıkla kullanılmaz ve tarihsel öneme sahiptir. Ancak tiroit fizyolojisini ve günümüz çalışmalarının anlaşılması için önemlidir.

\subsection{T3 süpresyon testi:}

Testin sınırda Graves ve otonom fonksiyone glandın tanısı için klinik kullanımı vardır. T3 süpresyon testinde bazal 24 saatlik uptake elde edilir. Hasta daha sonra 25 mcg T3 den, sekiz gün boyunca günde dört kez alır. Yedinci günün başlangıcında 24 saatlik uptake ölçümü yapılır. Tiroit supresyonunun normal cevabı uptake in bazalin \% 50' sinden ve genelin de \% 10' undan daha az düşme göstermesidir. Otonom fonksiyone bez süprese olmayacaktır. Günümüzde çok sensitif TSH testleri ile hipertiroidizm erkenden dedekte edilebilmektedir.

\subsection{TSH stimülasyon testi}

Test primer hipertiroidiyi sekonder (hipofizer) hipotiroididen ayırmak için kullanılır. Egzojen TSH ya cevap yetersizliği primer hipotiroidizm göstergesidir. Sekonder hipo- tiroidizmli hastalarda TSH stimülasyonundan sonra artmış radyoaktif iyot uptake'i gözükür. Stimülasyon testinde önce bazal 24. saat radyoaktif iyot uptake yüzdesi ölçülür. Hastaya daha sonra intramüsküler TSH uygulanır. Bir sonraki gün \% RAIU ölçümü yapılır. Sağlıklı kişiler ve hipopitüatirizmi olanlarda uptake iki katına çıkar, primer hipotiroidizmi olanlar ise yanıt göstermezler.

\subsection{Perklorat kovma testi}

Perklorat kovma testi tiroidde yakalama ve organifikasyon fonksiyonları arasındaki uyumsuzluğu gösterir. Bu durum konjenital enzim defektlerinde, kronik tiroiditte ve propiltiourasil tedavisi sırasında ortaya çıkar. Hasta uptake dozu radyoaktif iyot alır. İyot uptake'i 1-2 saat sonra ölçülür. Bir gram potasyum perklorat oral olarak verilir ve saatlik olarak uptake yüzdesi ölçülür. İyot uptake'inde \% 10'un üzerinde azalma organifikasyon defektini destekler (Ziessman ve ark., 2006).

Sonuç olarak, nükleer tıp yöntemleri benign ve malign tiroit hastalıklarının tanı ve tedavisinde anatomik görüntüleme yöntemlerinin yanında tamamlayıcı, güçlü bir yere sahiptir. ${ }^{99 \mathrm{~m}} \mathrm{Tc}$ perteknetat ve radyoaktif iyot ile yapılan tiroit, tüm vücut görüntüleme ve uptake çalışmaları hasta yönetiminde çok değerli bilgiler vermektedir. PET ajanlarının ve SPECT/ $\mathrm{BT}$ ve PET/BT gibi hibrit cihazların klinik kullanıma girmesi görüntüleme metodolojisini daha da iyileştirmiştir. Yakın gelecekte tiroit ile ilgili gerek görüntüleme gerekse tedavi ile ilgili yeni gelişmelerin, uygulamaları zenginleştirmesi beklenmektedir.

\section{KAYNAKLAR}

Abraham, T., Schöder, H., 2011. Thyroid cancer-indications and opportunities for positron emission tomography/computed tomography imaging. Semin. Nucl. Med. 41, 121-138.

Becker, D.V., Charkes, N.D., Hurley, J.R., McDougall, I.R., Price, D.C., Royal, H.D., Sarkar, S.D., 1999. Society of Nuclear Medicine Procedure Guideline for ThyroidScintigraphyversion 2.0

Boelaert, K., Horacek, J., Holder, R.L., Watkinson, J.C., Sheppard, M.C., Franklyn, J.A., 2006. Serum thyrotropin concentration as a novel predictor of malignancy in thyroid nodules investigated by fine-needle aspiration. J. Clin. Endocr. Metab. 91, 4295-4301.

Brendel, A.J., Guyot, M., Jeandot, R., Lefort, G., Manciet, G., 1988. Thallium-201 imaging in the follow-up of differentiated thyroid carcinoma. J. Nucl. Med. 29, 1515- 1520

Cooper, D.S., Doherty, G.M., Haugen, B.R., Kloos, R.T., Lee, S.L., Mandel, S.J., Mazzaferri, E.L., McIver, B., Pacini, F., Schlumberger, M., Sherman, S.I., Steward, D.L., Tuttle, R.M., American Thyroid Association (ATA) Guidelines Taskforce on Thyroid Nodules and Differentiated Thyroid Cancer, 2009. Revised American Thyroid Association management guidelines for patients with thyroid nodules and differentiated thyroid cancer. Thyroid. 19, 1167-214

Değer, M., Demir, M., İnce, M., Kıraç, S., Köseoğlu, K., Turan, E., Uysal, B., 2004. Kalite kontrol, enstrumantasyon ve radyasyon güvenliğ komitesi yönergesi. Turk J. Nucl. Med.13,151-169.

Diagnostic accuracy of 18F-FDG PET in restaging patients with medullary thyroid carcinoma and elevated calcitonin levels. J. Nucl. Med. 48, 501-507.

Diehl, M., Graichen S., Menzel, C., Lindhorst, E., Grünwald, F., 2003. F-18 FDG PET in insular thyroid cancer. Clin. Nucl. Med. $28,728-731$.

Diehl, M., Risse, J.H., Brandt-Mainz, K., Dietlein, M., Bohuslavizki, K.H., Matheja, P., Lange, H., Bredow, J., Körber, C., Grünwald, F., 2001. Fluorine-18 fluorodeoxyglucose positron emission tomography in medullary thyroid cancer: Results of a multicentre study. Eur. J. Nucl. Med. 28, 1671-1676.

Haugen, BR., Lin, E.C., 2001. Isotope imaging for metastaic thyroid cancer. Endocrinol. Metab. Clin. North Am. 30, 469-492.

Joyce, J.M., Swihart, A., 2011. Thyroid: Nuclear medicine update. Radiol. Clin. North. Am. 49, 425-434.

Ma, C., Kuang, A., Xie, J., Ma, T., 2005. Possible explanations for patients with discordant findings of serum thyroglobulin and 131I whole-body scanning. J. Nucl. Med. 46, 1473-1480.

Ong, S.C., Schöder, H., Patel, S.G., Tabangay-Lim, I.M., Doddamane, I., Gönen, M., Shaha, A.R., Tuttle, R.M., Shah, J.P., Larson, S.M., 2007. Diagnostic accuracy of 18F-FDG PET in restaging patients with medullary thyroid carcinoma and elevated calcitonin levels. J.Nucl.Med. 48, 501-507.

Palmedo, H., Bucerius, J., Joe, A., Strunk, H., Hortling, N., Meyka, S., Roedel, R., Wolff, M., Wardelmann, E., Biersack, H.J., Jaeger, U., 2006. Integrated PET/CT in differentiated thyroid cancer: Diagnostic accuracy and impact on patient management. J. Nucl. Med. 47, 616-624.

Sarkar, S.D., Kalapparambath, T.P., Palestro, C.J., 2002. Comparison of $123 \mathrm{I}$ and 131 I for whole-body imaging in thyroid cancer. J. Nucl. Med. $43,632-634$ 
Shankar, L.K., Yamamoto, A.J., Alavi, A., Mandel, S.J., 2002. Comparison of 123 I scintigraphy at 5 and 24 hours in patients with differentiated thyroid cancer. J. Nucl Med. 43, 72-76.

Shiga, T., Tsukamoto, E., Nakada, K., Morita, K., Kato, T., Mabuchi, M., Yoshinaga, K., Katoh, C., Kuge, Y., Tamaki, N., 2001. Comparison of (18)F-FDG, (131)I-Na, and (201)Tl in diagnosis of recurrent or metastatic thyroid carcinoma. J. Nucl. Med. 42, 414-419.

Töre, G., Karayalçın, B., Esen, B., Türkmen, C., Yüksel, D., Varoğlu, E., Özkılıç, H., Kabasakal, L., Yüksel, M., Kır,. M.K., Özdoğan, Ö., Atasever, T., 2003. Tiroid sintigrafisi uygulama kılavuzu. Turk. J. Nucl. Med.12, 178-180.

Yüksel, D., Argon, M., Atasever, T., Çelen, Y.Z., Kabasakal, L., Karayalçın, B., Kır,. K.M., Özdoğan, Ö., Özkılıç, H., Sarı, O., Türkmen, C., Varoğlu, E., Yapar, A.F. Yüksel, M, 2001. Differensiye Tiroid Kanserlerinde Radyoaktif İyot (I-131) Ablasyonu ve Tedavisi Uygulama Kilavuzu, Turk J. Nucl. Med. 10, 1-27.

Ziessman, H.A., O’Malley, J.P, Thrall, J.H., 2006. Endocrine System. In The Requisites, Nuclear Medicine, third edition, Mosby Elsevier, Philadelphia, pp. 71-99. 